\title{
Construction History and Research of the Holy Trinity Parish Church in Szigetmonostor
}

\author{
Ágnes Gyetvainé Balogh* \\ 1 Department of History of Architecture and Monument Preservation, Faculty of Architecture, Budapest University of Technology and \\ Economics, H-1111 Budapest, 3 Múegyetem rkp., Hungary \\ * Corresponding author, e-mail: gyetvaine.balogh.agnes@epk.bme.hu
}

Received: 30 July 2020, Accepted: 30 November 2020, Published online: 03 May 2021

\begin{abstract}
The church of Szigetmonostor, together with the parish building in front, and the late chanter house next to it, is the characteristic complex of its environment. Its plan with the middle tower façade solution is a classic example of Baroque church architecture of the eighteenth century. The most valuable part of the building is the late Baroque pulpit renovated while keeping its original appearance. Szigetmonostor - earlier Monostor - a municipality in Pest County on the Szentendre Island came into the possession of the Zichy family after the Turkish rule. In the 1730s, Ferenc Zichy put the tenure in pawn to Gábor Horányi, a servant judge in Pest County, who started greater developments here by building a castle (today the parish) and a church in the 1740s. The tower was built in front of the main façade a few years after the completion of the nave. The Vienna Court Chamber acquired the manor from the Zichy family in 1766 after a long lawsuit, also redeeming Monostor from the Horányi family. In 1774, the master masons Mihály János Hamon and Jakab Gföller were commissioned to survey the buildings of the manor, which came into the possession of the Crown from the Zichys. Their survey plans illustrate the church with the small teaching house and church garden next to it. During the $19^{\text {th }}$ and $20^{\text {th }}$ centuries, the church underwent several renewals and renovations and minor alterations that could be tracked with the help of records and Canonica Visitatios.
\end{abstract}

\section{Keywords}

Szigetmonostor, Baroque church architecture, surveying plans from the $18^{\text {th }}$ century

\section{Introduction}

Szigetmonostor is a municipality in Pest County on the Szentendre Island. The Roman Catholic Church built in the honour of the Holy Trinity has been a monument since 1958 (Fig. 1). ${ }^{1}$

This study is based on the construction historical scientific documentation, written in the spring of 2016 upon the assignment of the parish of Holy Trinity in Szigetmonostor (Gyetvainé Balogh, 2016; Gyetvainé Balogh, 2020). The aim of the paper is to provide the technical basis for the restoration of the building that is under national level monument protection, and to offer effective help with its recommendations. The document also utilizes the results of studies written prior to renovation on wood preservation, statics, the restoration of furnishings (altar, pulpit, organ), and the architectural survey of the church.

137 Fő street (parcel no.: 138) Heritage: 7341. prime number, registration ID: 7411. Until the 1990s it was heritage in nature. (Genthon, 1951:p.357; Gólya, 1960:p.335; Ikafalvi, 1990:p.917)

\section{Architectural design of the church}

The small-sized, provincial Baroque church is located on the street line, with its main façade looking east. It mostly preserved its original pattern. It is a symmetric building with a mono pitch roof encircled by garden from the South. The four storey tower jutting out of the plane of the face is covered by a steeple in a four-edged curved pyramid form (Figs. 2 and 3). The sanctuary is straight closed, with diagonally cut corners and a sacristy on each side (Figs. 4 and 5).

Its plan is a classic example of Baroque church architecture of the eighteenth century. The three-staged nave covered by basket-handle arched Bohemian (spherical) vaults (suspended domes) is extended by niches, the corners of the sanctuary are rounded inside.

The present-day altar - a simple altar table made of Tardos red marble - was made in the 1970s together with the ambo. The Holy Sepulchre altar stands at the southern part of the nave. The one-time main altar's tabernacle made at the end of the $18^{\text {th }}$ century - after the rearrangement of the liturgic space of the chancel - was moved here, 


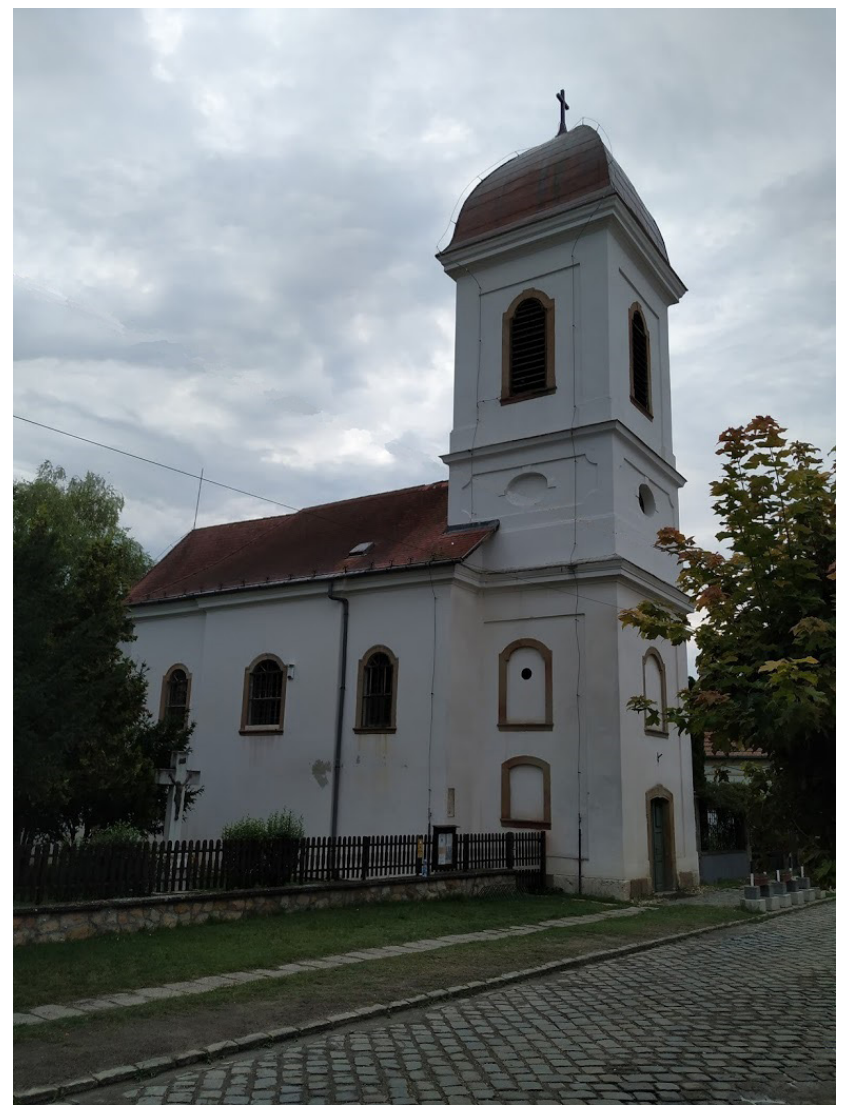

Fig. 1 The church from the South, 2020.
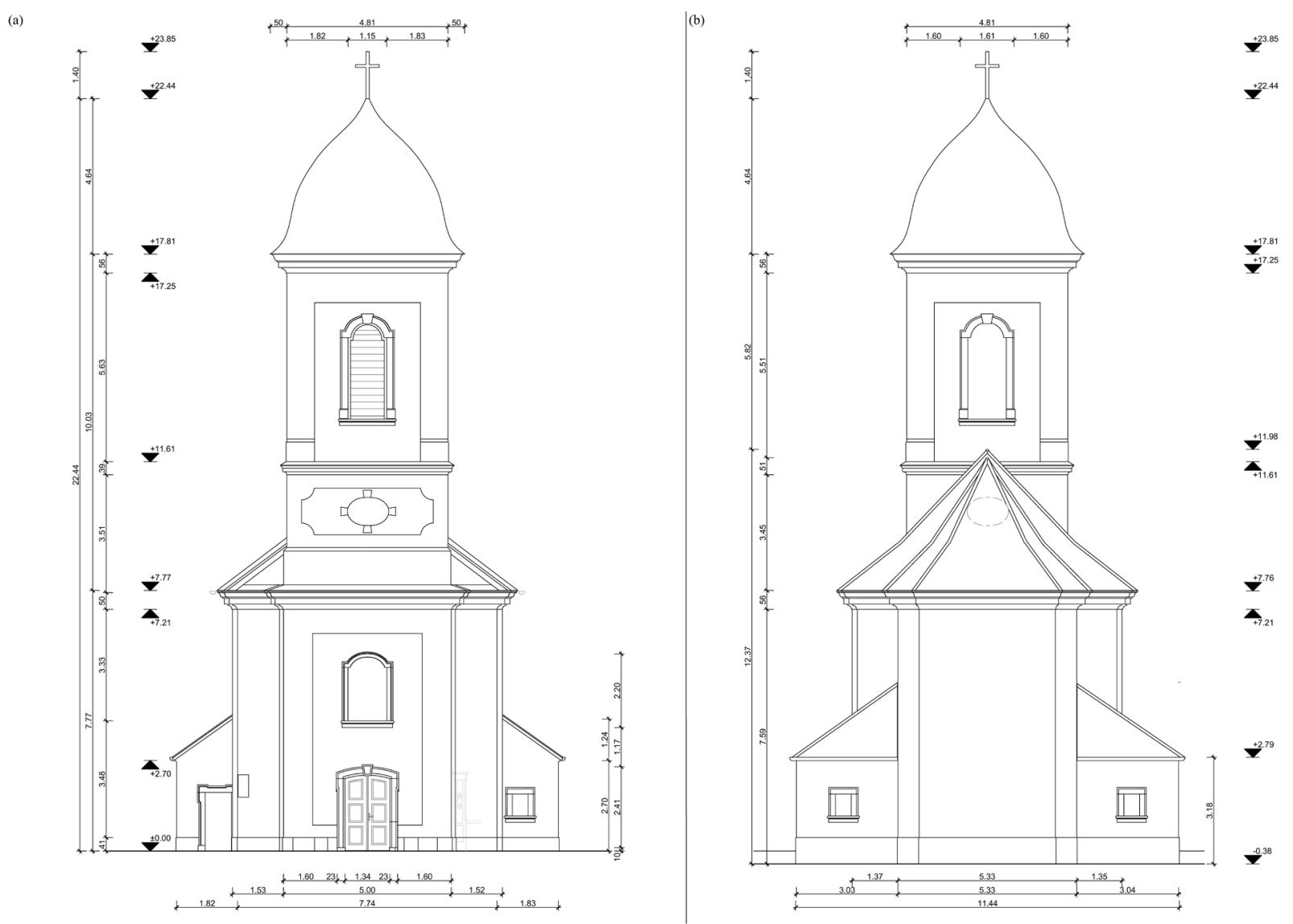

Fig. 2 (a) The Eastern and (b) Western facades of the church. Survey plan, Géza Gyetvai, Péter Gyetvai, Vince Nemes, 2016 (TP). 


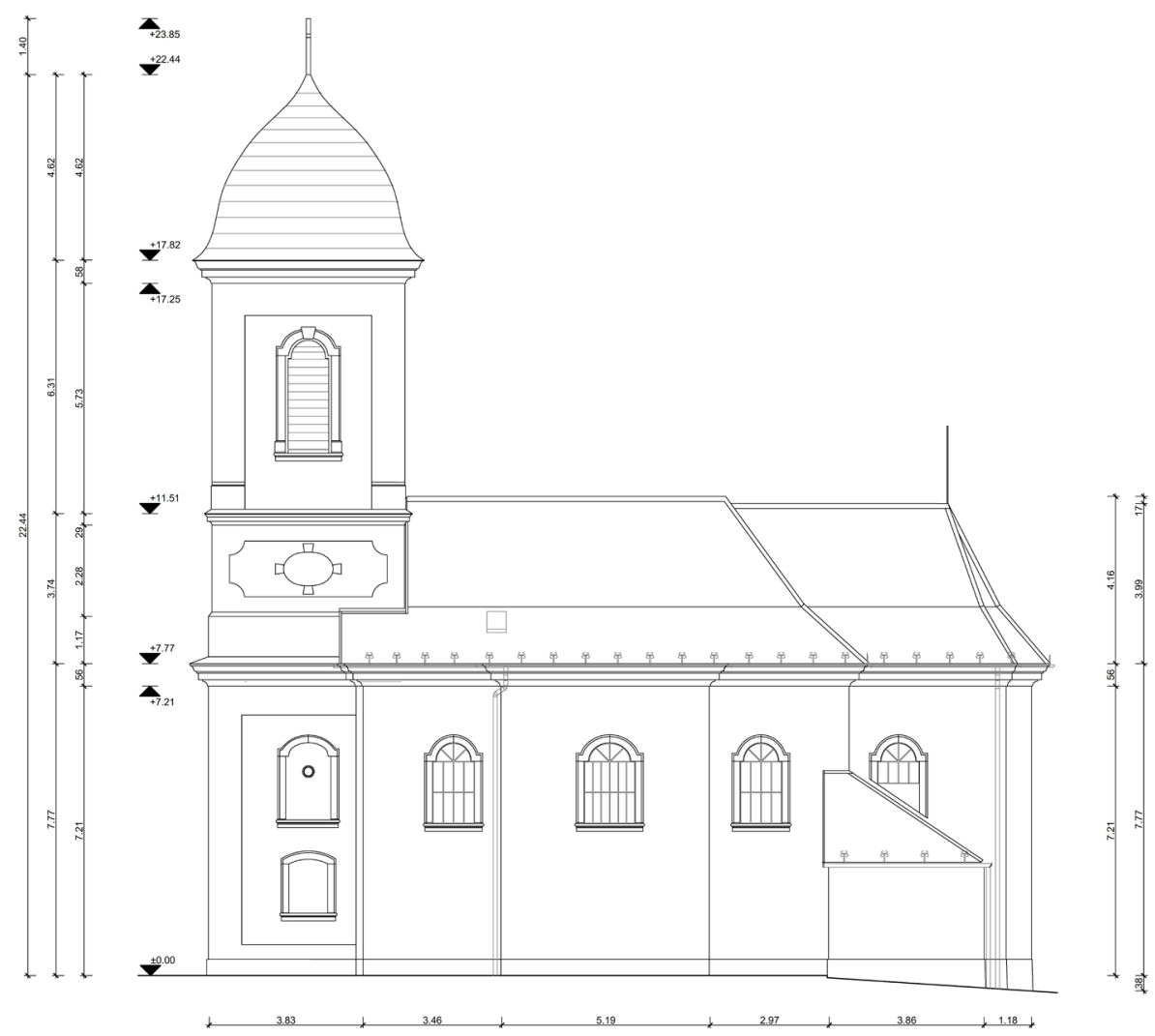

Fig. 3 The Northern facade of the church. Survey plan, Géza Gyetvai, Péter Gyetvai, Vince Nemes, 2016 (TP).

to an altar table made of artificial stone. Two late Baroque angels dating back to the 1760-1770s stand at both sides of the tabernacle (Fig. 6).

The pulpit carved from wood was also made around 1760-1770s, it is a significant piece of the Hungarian late Baroque art. It is situated at the northern side of the church, at the meeting point of the triumphal arch and the nave, accessible through a door cut out from the sacristy into the wall. The baptistery made of red marble was also created at the end of the $18^{\text {th }}$ century.

The frescos of the sanctuary and the vault were painted by Ernö Jeges in 1952. The main altar picture depicts the Holy Trinity with Hungarian saints and the view of the village. Two tondos - portraits of St. Joseph and St. Vendel were made above the two sacristy doors. The praise of the Eucharist is represented on the vault of the sanctuary, while on the ceiling fresco of the following vault section Holy Mary can be seen with the choir of the angels when she is being taken into heaven. The topic of the widest vault section is the teaching Christ with the Sermon on the Mount.

The desks were made in 1900, the Rieger organ standing on the gallery was built in 1914. The confessional booth situated at the southern side under the gallery is also the work of the $20^{\text {th }}$ century, with Holy Virgin Mary's altar placed in front of it.
Three bells are hanging in the tower of the church, all of them made in the 1920s. The big bell was ladled in memory of the heroes fell in the world war, the middle in honour of St. László and the little one in praise of St. Thérèse de Lisieux.

\section{Tenure history of Szigetmonostor in the $17-18^{\text {th }}$ centuries}

After the recapture of Buda in 1686, István Zichy and later the Zichy family became the owners of the Zsámbék (later Óbuda) manor. The manor consisting of only 12, territorially not even adjacent settlements (Óbuda, Szentendre, Zsámbék, Tótfalu, Monostor ${ }^{2}$, Bogdán, Tök, Budakeszi, Szántó, Budaörs, Perbál and Békásmegyer) was taken into the possession of István Zichy first as a deed of gift given by Lipót in 1659, then de facto too, after the 1686 recapture. However, soon many started to argue upon Zichy's rights of ownership, including the Vienna Court Chamber that wanted to take possession of the whole territory around Buda (Horler, 1962:p.338; L. Gál, 1988:pp.46-49, 212, 218; L. Gál, 2004:p.16).

2 The municipality got its name from the monastery that stood here in the middle ages, the name Szigetmonostor first appeared in 1848. (Dercsényi, 1958:II.:p.139; Gerevich, 1986:pp.300-301; Györffy, 1998:pp.701-702; Bottlikné Grósz, 2007:p.9). 


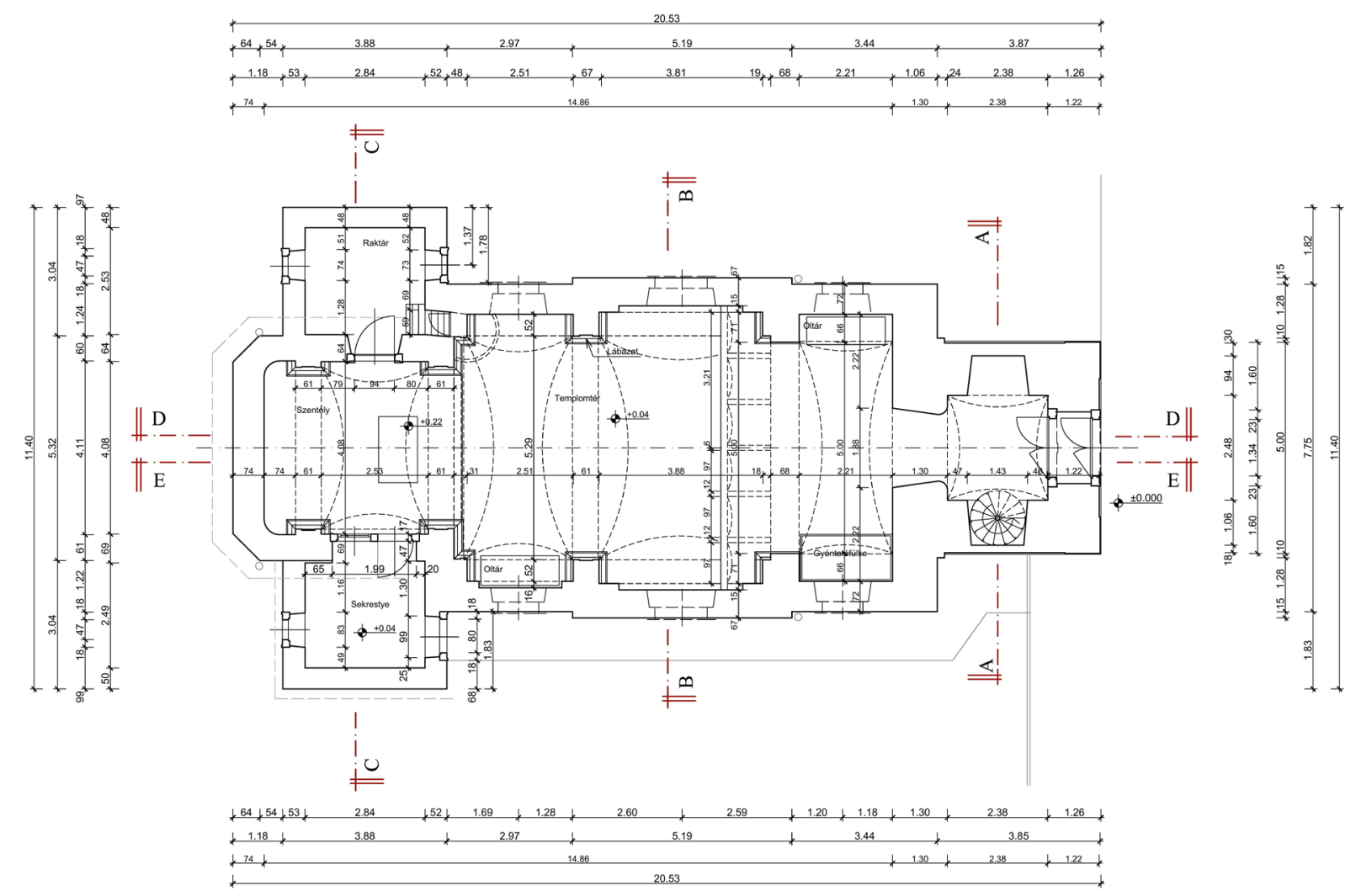

Fig. 4 The ground plan of the church. Survey plan, Géza Gyetvai, Péter Gyetvai, Vince Nemes, 2016 (TP).

5.

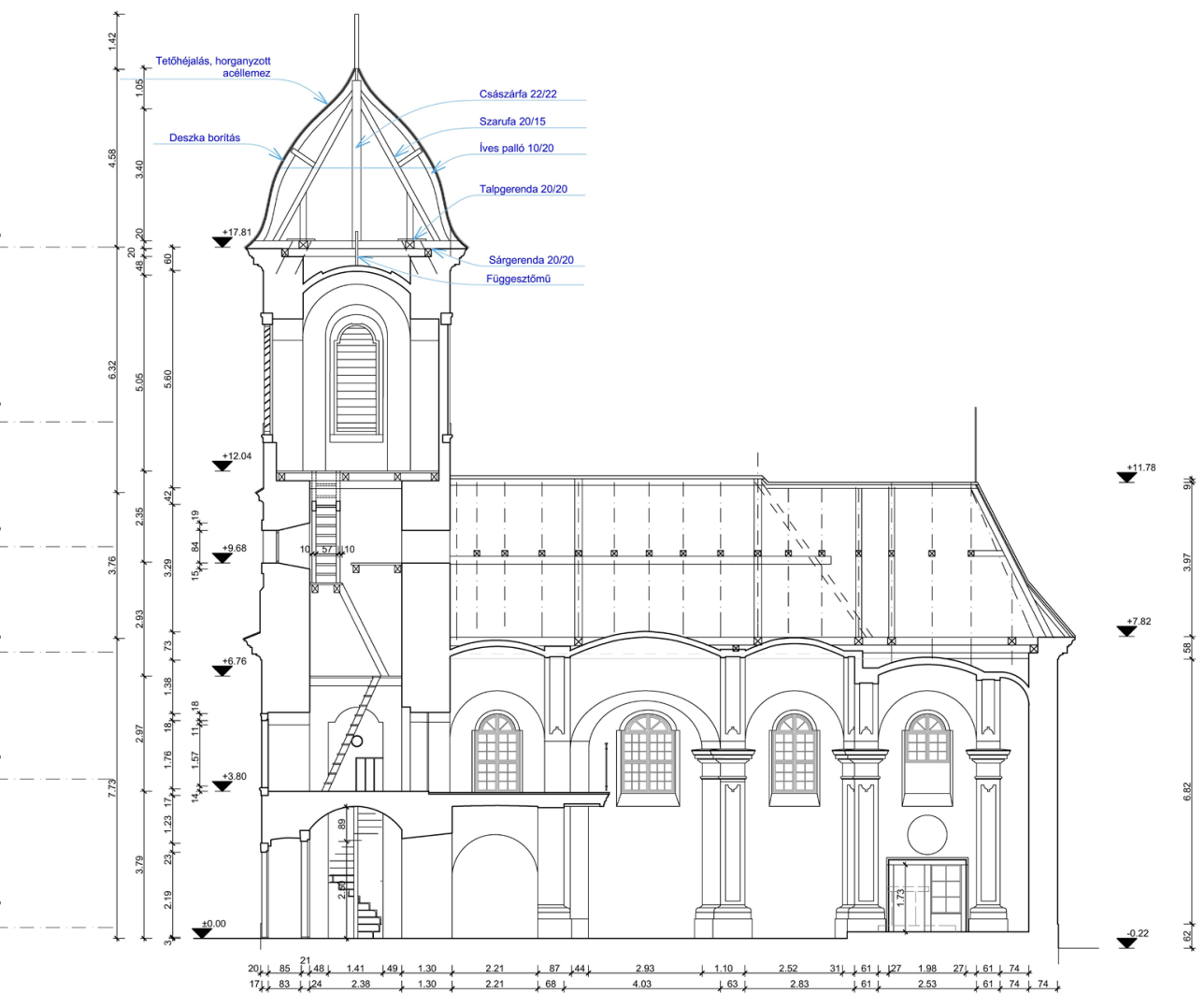

Fig. 5 Longitudinal section of the church. Survey plan, Géza Gyetvai, Péter Gyetvai, Vince Nemes, 2016 (TP). 


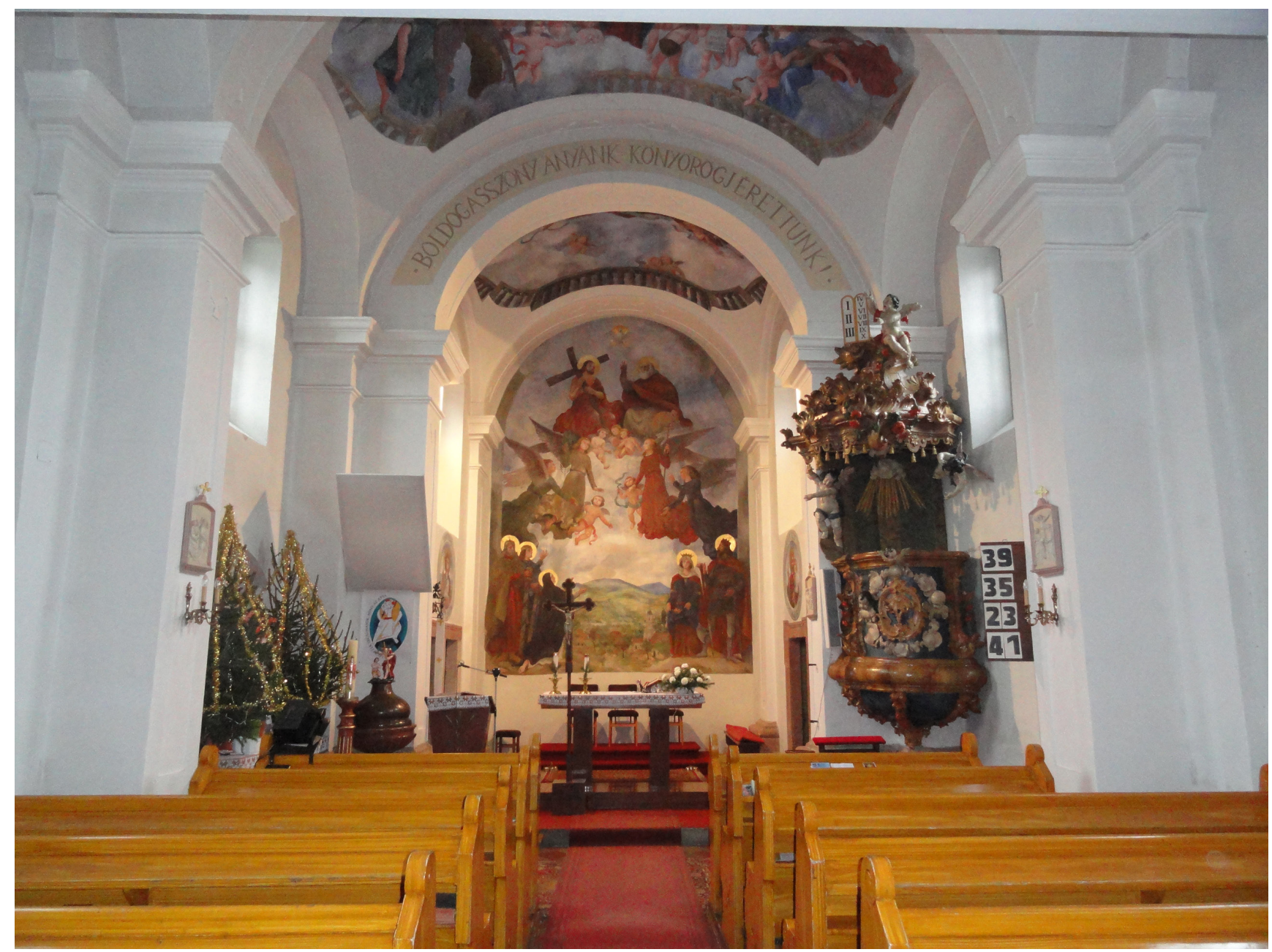

Fig. 6 The internal space of the church, 2016.

The manor was in the ownership of four successive generations of the Zichy family for one century. After István Zichy (1616-1693), his son, István Zichy became the land holder between 1693-1700, then for three years the manor was divided up between his sons, Péter and László. After the death of László in 1703, Péter (?-1726) became the owner, who regularly took loans and put his tenures in pawn (Horler, 1962:p.338). ${ }^{3}$

After the death of Péter Zichy, his wife, Zsuzsanna Bercsényi and his son, Miklós (1709-1758) got involved in a long lasting litigation for the manor with the sons born from the first marriage of Péter Zichy. The lawsuit ended with the victory of the widow and her son, however, Monostor was given to Ferenc Zichy, who put the tenure in pawn soon.

3 MNL OL P 707. Zichy család levéltára, (Archives of the Zichy family) Vol. 601. Ferenc Radnai: Zichy nemesi és grófi család története, életrajza és leszármazása. (Patrician and earl family history, biography and ancestry of the Zichy family) Manuscript, end of the $19^{\text {th }}$ century.
Monostor was pledged to Auer, late brewer from Óbuda, then to the constable of Pest County, Gábor Horányi, who possessed it for more than three decades together with his son, Antal (Bakács, 1963:pp.7-8, 140; L. Gál, 1988:pp.54-55; Gyetvainé Balogh, 2008:pp.189-192).

After Miklós Zichy decayed without a successor in 1758, the Chamber got involved in another litigation with his widow, Erzsébet Berényi (?-1796). The earls of the Zichy family also launched a lawsuit against her for the possession of the manor. According to the agreement made in 1766 the Chamber exchanged the manor of Óbuda from the widow for cash and perpetuity, as to the Zichy earls, they were compensated. Therefore, the patronage of Monostor was under the competence of the ministry of finance until 1891, then it was passed over to the ministry of agriculture. The Chamber sold the manor to the Metropolitan Waterworks in December, 1934, hereby, starting from 1935, Székesföváros became the new patron (L. Gál, 1988:pp.49-59, 212, 218; Dercsényi, 1958:I.p.128; SZPL 4542. Sz.n./1938). 


\subsection{The Hamon-Gföller surveys}

After the Zichy agreement the Chamber returned Monostor from pledgee Antal Horányi back as far as at the end of 1766 (Bakács, 1963:pp.7-8, 140; L. Gál, 1988:pp.49-59, 212, 218). Following the acquisition of the manor a survey started focusing on the whole territory and building stock. Andreas Kneidinger made his map sequence about the municipalities $^{4}$ of the late Zichy manor in the 1770s (1776-1770), providing a thorough presentation of the buildings, land allocation and street network of Monostor, too (Fig. 7).

In the same time, two master masons were commissioned to prepare a registry and technical accounts about the building stock. According to the chamber decree of $11^{\text {th }}$ of January, 1774, master masons János Mihály Hamon ${ }^{6}$ from Buda and Jakab Gföller from Gödöllő surveyed the manor's buildings on the 12 municipalities acquired by the Chamber, ${ }^{7}$ many of these edifices were situated in Monostor (Gy. Balogh, 2008:pp.196-221). ${ }^{8}$ The preserved series of plans and descriptions record the then use and condition of the buildings, providing valuable architecture historical sources.

\section{The church plot}

The Hamon-Gföller survey thoroughly illustrates the church plot too. ${ }^{9}$ Accordingly, the church stood at the north-eastern corner of the plot, as it does so today (Fig. 8 (a)).

4 MNL OL S 11. No. 830:1-97. Kneidinger Atlas; S 11. 830:68 in it. (sections 73-74) The overview map of the Crown Manor of Óbuda. A. Kneidinger, 1778.

5 MNL OL S 11. No. 34. The survey map of Monostor, part of Óbuda Crown Manor. A. Kneidinger, 1778; MNL OL S 11. No. 830:70. Survey and agricultural map of Monostor periphery. A. Kneidinger, 1778; MNL OL S 11. No. 830:82. The agricultural map of Monostor's periphery. A. Kneidinger, between 1767-1779.

6 About the life and work of J. M. Hamon (1729-1796) see Gy. Balogh, 1998:pp.300-301.

7 MNL OL T1 Fasc. 2. No. 167-200; T1 Fasc. 3. No. 201-226; T62 No. 1. 188, 197, 216. The description of the plans: T1 Fasc. 6. No. 576. fol. 201-220. Cost estimates of the mason-works of the building stock, 1783: MNL OL T1 Fasc. 6. No. 577. fol. 221-244.

8 MNL OL T1 II. 188./1-2. The port pub of Monostor-Szentendre; 189./1-2. The brickyard and sheepcote of Monostor; 190./1-2. The barn and threshing floor of Monostor manor; 191/1-2. The Roman Catholic Church and teaching house; 192/1-2. The lord house of Monostor; 222/1-2. The so-called "Tótfalu manorial" port pubs of Vác and that of Monostor-Dunakeszi. The descriptions of the plans: MNL OL T1 Fasc. 6. No. 576. fol. 216-217.

9 MNL OL T1 II. 191/1. The plan and cross-sectional view of the Roman Catholic Church and Teaching House of Monostor /Pest County/ with the plan of the garden. /Joh. Mich. Hamon/ $18^{\text {th }}$ century.
At that time, the plot consisted of a garden divided into parterres, with a cornfield behind it. There were trees or bushes along the roads of the garden. The asymmetric allocation of the garden could be explained by the fact that the entrance and the middle axis were formed within the axis of the main entrance of Horányi Castle built opposite to the church.

The form of the plot did not change in the course of the nineteenth century, its formation and cultivation are not known. Regarding its size, it underwent certain change in 1989, when Gyula Biber parish priest gave 116 square feet of the church garden for the sake of the newly built clerk teacher's house. Namely, it was in 1898 when the community decided to extend the classroom of the school operating in the building of the parish, and to build a new house next to the church replacing the previous one being "in a dilapidated state". They annexed 116 square feet to this 71 square feet plot of the house in order to construct a building with an appropriate size. ${ }^{10}$

The plot and possession of the church did not change in the course of the following century, its owner was the Szigetmonostor Roman Catholic Church and it remained so.

\section{Building history and contemporary design of the church}

\subsection{The circumstances of the construction}

Gábor Horányi (?-1764), who was the emissary to parliament of Pest County starting from 1737, and deputy land agent from 1747, built his palace - nowadays under 25 Mihály Táncsics street - in the Buda Castle in the 1740s. Although, he acquired Monostor only as the pledgee, soon he started greater developments here by building a castle and a church in the 1740s. "He set up a house chapel with a tower entrance" in the castle (today under 38 Fö street, the parish), officiating in it until the church was completed in 1752. He supported Catholics to settle down in the village that's dominant religion had been Calvinism, and brought monks from Buda for the officiatings to strengthen the Catholic faith (Dercsényi, 1958:II.:p.139, pp.142-143; Kiss, 1996:p.7; Bottlikné Grósz, 2007:p.11). ${ }^{11}$

The exact time of the construction of the castle is proven by the stamped bricks found within the building. The most common convex inscription occurring in the attic and around the courtyard is: "17 GH 43". The manually written intertwined letters of "G" and " $\mathrm{H}$ " represent the monogram of Gábor Horányi, and the year is 1743 .

10 SZPL 4542. 14 June 1898. Protocol; No. 575/1939.; No. 1968/1898.; Sz.n./1938

11 SZPL 4542. Sz.n./1938 


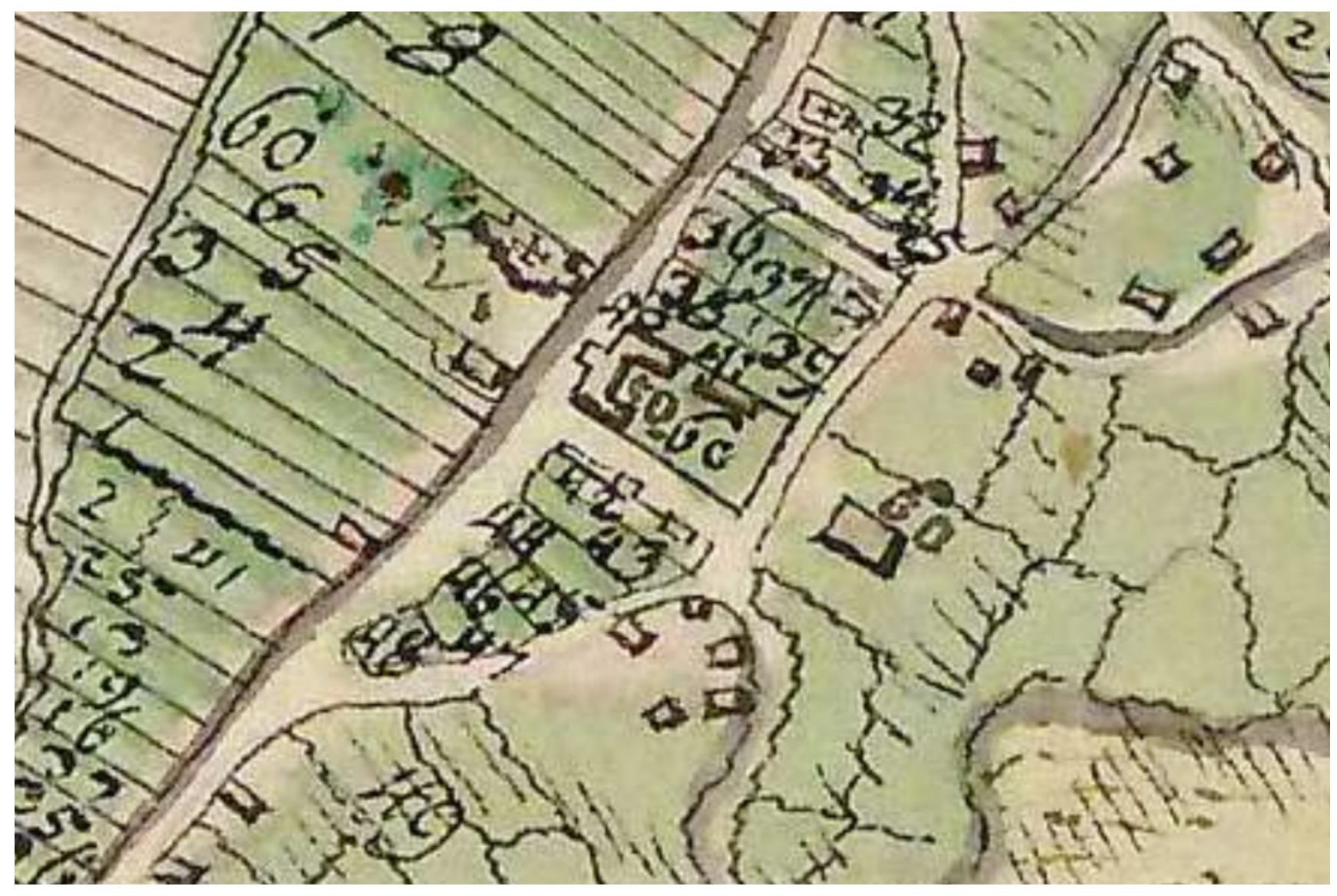

Fig. 7 In the middle the U-shape Horányi Castle opposite to the Roman Catholic church and the small teaching house. Detail from the survey map of Monostor. A. Kneidinger, 1778. (MNL OL S 11. No. 34.).

Inscriptive bricks of "17 GH 44" and "17 GH 47" can also be found but in smaller quantities (Gy. Balogh, 2000; Gyetvainé Balogh, 2008:p.197).

The construction of the castle, and the church opposite to it happened more or less in the same time. According to local Calvinist sources the church was built in 1740, then the tower in 1750 or 1755 . A parish priest questioned the later construction of the tower in 1937, because he found 1743 and 1745 GH inscripted bricks in the tower. ${ }^{12}$

Local observations, however, still prove that the church was built in two stages. First, it was constructed without the tower, together with a gate that's shape is identical to the stone framed gate that of today, with a horizontal oval opening in the gable pane, then the tower was built in front of the main façade of the church. The Calvinist sources mentioned in 1937 must have been right, because we found a brick in a wall nest at the lower part of the tower inscripted by 1747 , as well as a walled-up brick with

12 SZPL 4542. No. 2476/1937. In his letter, János Scholtz refers to Calvinist parochial papers when he mentions tower building date of 1750; SZPL 4542. Sz.n./1938. - here, 1755 is the date of tower construction. an inscription of 1755 at the uppermost part, and another inscripted brick having 1750 carved in it with the mentioned GH monogram at the corner of the apse in the attic.

Another proof of the tower's later construction is the horizontal oval opening in the gable of the nave, which is the only access to the attic ere now, but is situated $1.5 \mathrm{~m}$ above the vaults. Therefore, the reason of the placement was not to provide an appropriate access route to the attic but it followed decoration purposes. In other words, originally it was the opening of the main façade. The other, more important proof is the trace of the cornice - discoverable $1.5 \mathrm{~m}$ under the oval opening within the unplastered inner side of the tower - that was removed during the construction of the tower; it is apparent how the wall of the tower was built as an extension. The tower's later construction is also demonstrated by the fact that brick lines of the tower wall are not tied into the wall texture of the gable of the church.

On the surface of the unplastered inner side of the tower we can find two types of masonry techniques, hinting that the construction of the tower also took place in two stages. The gallery could have also been built later than the nave, because the brace holding the gallery starts out as being seated onto the stone plinths of the pilasters. After removing 

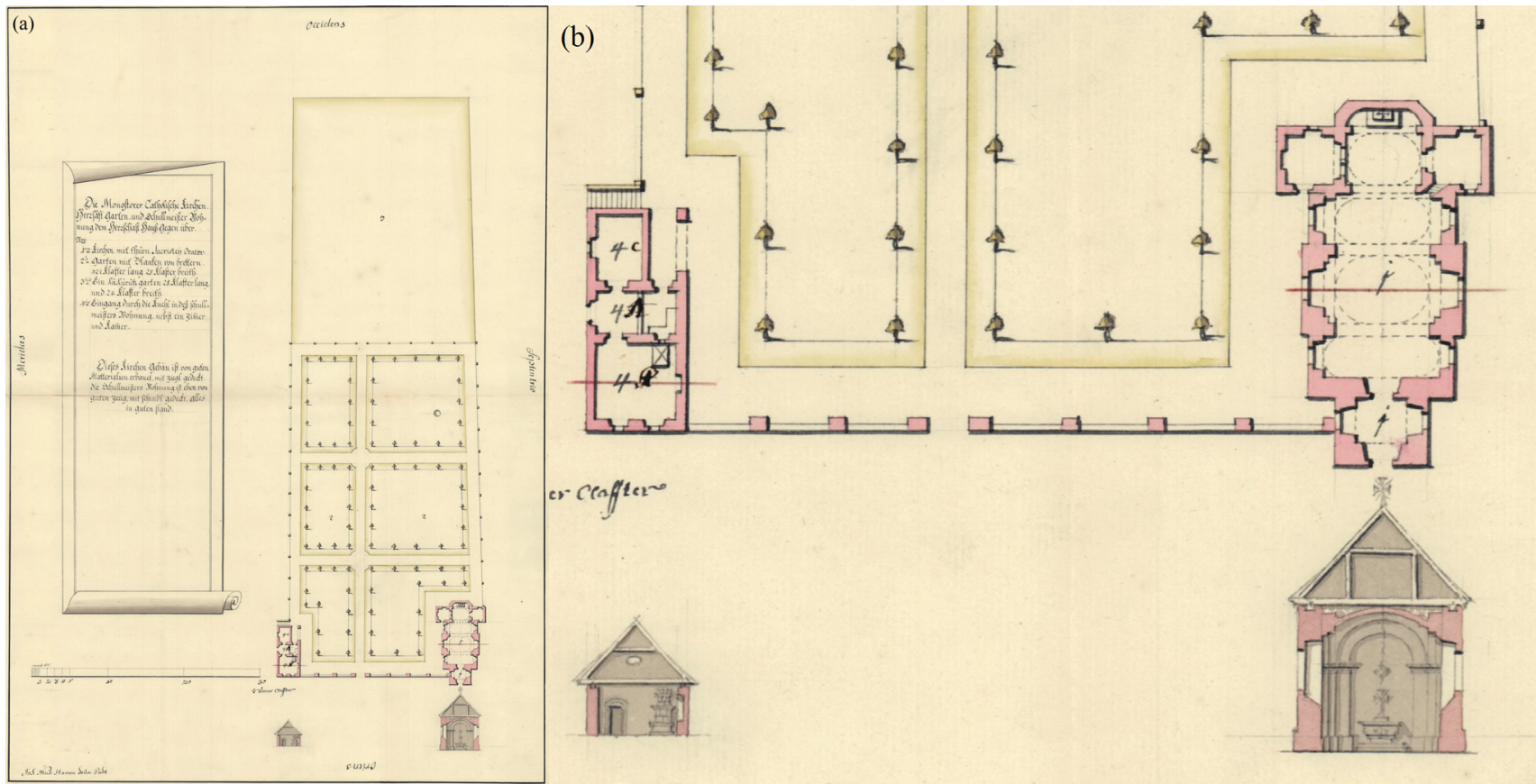

Fig. 8 (a) Plan and cross-section of the Roman Catholic church and teaching house of Monostor together with the plan of the garden. Joh. Mich. Hamon, 18 ${ }^{\text {th }}$ century (MNL OL T1 II. 191/1.) Legend (in German): "Die Monostorer Catholische Kirchen, Herzsaft Garten, und Schullmeister Wohnung dem Herzschaft Haus Gegen über. Nro. 1-mo Kirchen mit Thurn, Sacristey Orator. 2-do Garten mit Blanken von brettern. 42 1/2 Klafter lang 25 Klafter breith. 3-tio Ein Kukurutz Garten 28 Klafter lang, und 24 Klafter breith. 4-to Eingang durch die Kuchl in deß Schullmeisters Wohnung, nebst in Zimmer und Kammer. Dieses Kirchen Gebäu ist von guten Matterialien erbauet, mit Ziegl gedeckt. die Schullmeisters Wohnung ist eben von guten Zeüg, mit Schindl gedeckt, alles in guten Stand" ("The Catholic church, the manorial garden and the schoolmaster's apartment opposite the manor house in Monostor. No. 1. Church with tower, sanctuary, oratorio. 2. Garden with planking. 42.5 fathoms long, 25 fathoms wide. 3. Cornfield 28 fathoms long, 24 fathoms wide. 4. Entrance through the kitchen into the schoolmaster's apartment, along with the room and chamber.

This church building is made of good materials, covered by tiles. The schoolmaster's apartment is just made of good stuff, covered by shingles, everything is in good condition."); (b) Plan of the Roman Catholic church. Joh. Mich. Hamon, 18 ${ }^{\text {th }}$ century (MNL OL T1 II. 191/1.).

the plaster in 1997, it became visible that the brace of the gallery is not intertwined with the wall texture of the church. The Bohemian (spherical) vault of the gallery is characteristic of eighteenth century architecture, it might yet have been built in the Horányi time (before 1766).

The church was completed by 1752, however we do not have any reference on whether it was finished with or without the tower and the gallery. Patron Gábor Horányi - in his letter written on the $15^{\text {th }}$ of August, 1752 to Márton Bíró Padányi bishop of Veszprém - reported that he finished the construction of the church raised in honour of the Holy Trinity and asked for his ordainment. In his letter written on the $8^{\text {th }}$ of September, the bishop, referring to his engagements, promised to send Mihály Márkus parish priest of Zsámbék to bless the church. In his charter dated yet on the $5^{\text {th }}$ of September he gave his credentials to Mihály Márkus, the dean of Buda deanery to benedict the newly equipped church (Pehm, 1934; Dercsényi, 1958:II.:p.140). ${ }^{13}$

13 SZPL Collection of I. Kuthy: Diary of Márton Padányi Bíró bishop of Veszprém, 1752-1753:p.240.
After Monostor became the property of the Chamber in 1766 and was taken back from the Horányi family, starting from 1768 it became an independent parsonage as part of the territory of the Veszprém episcopate. Previously it was an affiliated church of Bogdány (Dunabogdány). In 1777 it was moved to the episcopate of Székesfehérvár - which was formed just around that time -, then in 1993 it became the parsonage of the Archdiocese of Esztergom-Budapest. ${ }^{14}$ Hereby, the Horányi Castle provided residence for the parish

14 The original place of the documents concerning the establishment of the parish of Monostor are not known, they cannot be found neither at the parish, nor at the Episcopal Archives of Székesfehérvár: SZPL 4542. Sz.n./1896. According to the letter written by parish priest, Gyula Biber in 26 of July, 1896 the founding document could not be found at that time neither. The territory of the parish once extended to the territories of present-day municipalities of Tahitótfalu (until 1803) and to Pócsmegyer-Leányfalu (until 1937). Since 1937, the territory of the parish has been extended only to the territory of the municipality. (SZPL 4542. Sz.n./1938.; See the website of the Esztergom-Budapest Föegyházmegye: https://www.esztergomi-ersekseg.hu/plebaniak/ szentharomsag-plebania-szigetmonostor). 
starting from 1768, the parish priest lived in the northern part of the building. Starting from an unknown date, but surely by the beginning of the nineteenth century a school was already operating in one of the Southern chambers of the building, and the other rooms must have been given to manor officials during their field-work (Gy. Balogh, 2000). ${ }^{15}$

\subsection{The $18^{\text {th }}$ century survey plans of the church}

The survey plan made in $1774^{16}$ illustrates the church with the teaching house next to it (Figs. 8 (a) and (b)). According to the description of the plan the church was built with a tower, a sacristy and an oratorio (1). The manor's cultivated garden divided into parterres (2) is located next to it, surrounded by a planking, and a cornfield behind it (3). The tiny schoolmaster house (4), consisting of a room, a kitchen with an open chimney and a pantry stood at the southern corner of the garden. The survey described both buildings as being in good condition: made of good materials, the church was covered by tiles, the teaching house was covered by shingles.

The plan of the church is the same today: the three-staged nave extended by niches covered by Bohemian vaults (suspended domes), the sanctuary is directly closed with rounded corners. The braces separating the arch sections are the same, too, as well as the two secondary chambers together with all of the openings. The onetime altar table standing on the twostep substruction can also be seen on the section plan with a big cross above it, and a chandelier hanging from the arch. A dual suspension roof structure was illustrated that could be the same as the present-day framework.

In the plan, the marking of the arch section illustrated at the place of the gallery is different from the others, in other words, the niches are missing and the drawing does not include stairs. The pulpit is also missing, only the approach cut into the wall is illustrated. It cannot be decided, whether these were not finished by this time or the creator of the survey just did not illustrate the gallery and the pulpit. Since, the aim was not the accurate drawing of the building but to inform the Chamber about the sizes and condition of the buildings.

Compared to that of today's, a façade with a little bit different architecture can be seen on the other plan sheet of

15 It was used accordingly yet in 1817: SZPL 4542. Sz.n./1938.

16 MNL OL T1 II. 191/1. The plan and cross-sectional view of the Roman Catholic Church and Teaching House of Monostor /Pest County/ with the plan of the garden /Joh. Mich. Hamon/ $18^{\text {th }}$ century; T1 II. 191/2. The facade of the Roman Catholic Church and Teaching House of Monostor /Pest County/ Jacob Gföller/ $18^{\text {th }}$ century the church, ${ }^{17}$ with a complex bulbous steeple (Fig. 9). Apart from the steeple, further differences could be observed: the cornice is tripartite, the form of the gate is also different, the ground floor wall mirror is starting from the shoulder of the gate or the semicircular blind opening above it, and it is smaller. Here, and on the second tower stage the lesenes are double, the gable has volute, the bell windows are followed by an archivolt closing the tower. The planking with stone or brick pedestals distributed by pillars illustrated on the drawing is the same in its nature as the fence existing until 1980, although, the number of the fence sections is different.

It is important to note that the existence of this type of façade architecture differing from that of today's is uncertain. One can also point out differences, simplifications on the façade, concerning other surveys made by the two masters, that could not be explained by the later reconstructions but with the fact that the aim of the survey was to inform the chamber about the utility of the building stock, and not to precisely ingrain the details. This is the reason why the size and condition of the building are emphasised, these being the most important pieces of information. The architectural details on the façades were illustrated in simplified forms, therefore, these details of the Monostor church cannot be understood as authentic. However, it is likely that the tower had a compound steeple, not that simple that of todays'.

\subsection{The history of the building in the $18-19^{\text {th }}$ centuries}

The church underwent several renewals and reconstructions during the following century that could be tracked with the help of protocols and Canonica Visitatios. ${ }^{18}$

According to the Canonica Visitatio of $1778^{19}$ Horányi financed the construction of the church by episcopal tithes in 1752. "It is satisfactory for the reception of the people, without propriety. Its title is the Holy Trinity. It has one altar. It has eternal lantern that is not on in the absence of oil... Its equipment is sufficient, organ is old, and baptistery is inadequate. Its tower is made of good material, with three bells, the first measure about 5 quintals, the second is the Holy

17 MNL OL T1 II. 191/2.

18 Canonica Visitatios happened in 1778, 1799, 1805, 1817, 1829, 1839 and in 1868 too. The parish was the part of the Veszprém Diocese until 1877, but no data could be found about it in the Archives of the Bishopry of Veszprém. Document management between 1777-1816 was quite difficult in the Székesfehérvár Diocese, the documents were copied to crass protocollums, mostly without any index.

19 SZPL 4542. Canonica Visitatios 1778 (Collection of I. Kuthy). 
Trinity's with 2 quintals; the third is St. Gábor's; the latter and the second was consecrated by M. P. Bíró around 1756."

In April 1779, a fire destroyed the tower of the church, the sacristy and the roof of the teaching house, and the planking of the parish garden was also demolished to prevent the fire from spreading. One of the bells crashed and shattered, but the other two also melted. Caspar Reischl, a fortification and civilian carpenter in Buda, submitted a budget of 741 forints for the restoration of the church buildings and their covering with shingles, and then in June he planned two versions for the restoration of the tower's steeple. These views show complex bulbous steeples with clock ledges similar to Hamon's design (Fig. 10). ${ }^{20}$ In October of this year, Josephus Corte, an organist and instrumentalist master from Buda, made a plan for a new, positive organ that can be realized from 170 forints (Fig. 11). The amount requested from the Chamber increased to 916 forints and 13 pennies. In 1882, the cost of the organ was again mentioned in the documents, probably it was realized only after that. ${ }^{21}$

In 1780, an earthquake damaged the church again. ${ }^{22}$

According to the Canonica Visitatio of $1805^{23}$ the Royal Chamber renovated the church in 1792. It had one altar at that time, its eternal lantern was on only during holy masses. By this time it already had organ, the confessional and the baptistery made of red marble. Its furnishing was quite modest. From the above mentioned three bells, the one that was assigned to the honour of the Holy Trinity measured 3 quintals, the bell for the Holy Cross was about 2, and the Holy Virgin Mary was about 1 quintal. Ignác Nagy Sellyei (1777-1789) consecrated these bells.

1792 seems to be an important date in terms of reconstruction or renovation because some sources mistakenly mention it as the construction date (Borovszky, 1910:p.135; Ikafalvi, 1990:II.:p.917). It is possible that it was the time when the façade architecture visible in the survey plan was changed, and the form of the steeple was converted into a simpler type.

20 MNL OL T62. No. 179. Steeple to be built on the tower of the Catholic church in Monostor, two versions. Caspar Reischl, 1779. Documents relating to the plan: E 58. June 1779. No 484.

21 MNL OL T62. No. 216/8. Plan of the positive organ of the church in Monostor. Josephus Corte, Óbuda, October 1779. Documents relating to the plan: E 58. June 1782. No 316.

22 According to Kiss, 1996:p.12. the local buildings were not damaged. However, according to Bottlikné Grósz, 2007:p.11. the church did so. (This is confirmed by these news: "There was a powerful earthquake in the Pest-Buda-Komárom line at night around 20 past 10 on the 26 of August, 1780". Magyar Hírmondó, 1780:p.431, 462.)

23 SZPL 4542. Can. Vis. 1805. (Collection of I. Kuthy)
According to the Canonica Visitatio of $1817^{24}$ the church was just benedicted but was in a good condition, the steeple painted red, had three bells, the organ by the choir had 5 variations. The sacristy, the carved, painted pulpit, the baptistery made of red marble with the sculpture of John the Baptist on top of it, the altar made in honour of the Holy Trinity raised with wooden stairs together with 6 tin candleholders, and tabernacles were mentioned too. Its eternal lantern was only on during worship. Two "canvas paintings" - depicting Jesus and Holy Virgin Mary - on the wall were the part of the modest furnishings of the church at the time. The sculpture of John of Nepomuk standing next to the parish was raised in this year by believer József Dulitzky from Bogdány.

According to the Canonica Visitatio of 1829 "the shingle roof of the church was repaired again", the capacity of the church was sufficient and its condition was good. ${ }^{25}$

According to the Canonica Visitatio of 1839 the walls at the time demanded whitewash, the floor and the window frames needed repair. "The main altar swayed due to the frequent floods of Duna... And the flood of Duna damaging the altar's stamp broke. ${ }^{126}$ At this time three pictures were hanging in the church, two of them depicting the Holy Virgin Mary, the third portraying Jesus. Three bells were mentioned, the first of them (Holy Trinity) and the third (B. M. Virg.) were consecrated by Ignác Nagy (1777-1789), and bishop Mátyás Pál Szutsits benedicted the middle one in 1829.

The inventory made during the arrival of the new parish priest in 1866 also provides detailed information about the church. It lists the "big lantern in front of the altar", the "small lantern in front of the picture of Holy Virgin Mary", and six candle holders on the main altar and two at the picture of Holy Virgin Mary. It includes the confessional, a cupboard used for the church uniforms, softwood table and chair, tow angels on the altars, the God's Lamb, a footstool, a "kneeling chair for the parish clerk", the baptistery, a sculpture of the "Resurrection Christ", 10 pieces of different icons, coffin of Christ and three bells. It was recorded, that the building "remained in good condition by the end of 1866, since it became shingled by the Lordship that year - but its internal walls were not whitewashed, however it would be much in need."27

The description of Canonica Visitatio of 1868 mentions that the roof of the church and the tower shingle was renovated in 1866. At that time, the windows were still in bad condition.

24 SZPL 4542. Can. Vis. 1817. (Collection of I. Kuthy)

25 SZPL 4542. Can. Vis. 1829. (Collection of I. Kuthy)

26 SZPL 4542. Can. Vis. 1839. (Collection of I. Kuthy)

27 SZPL 4542. No. 479/1867. Inventory 31 December 1866. 


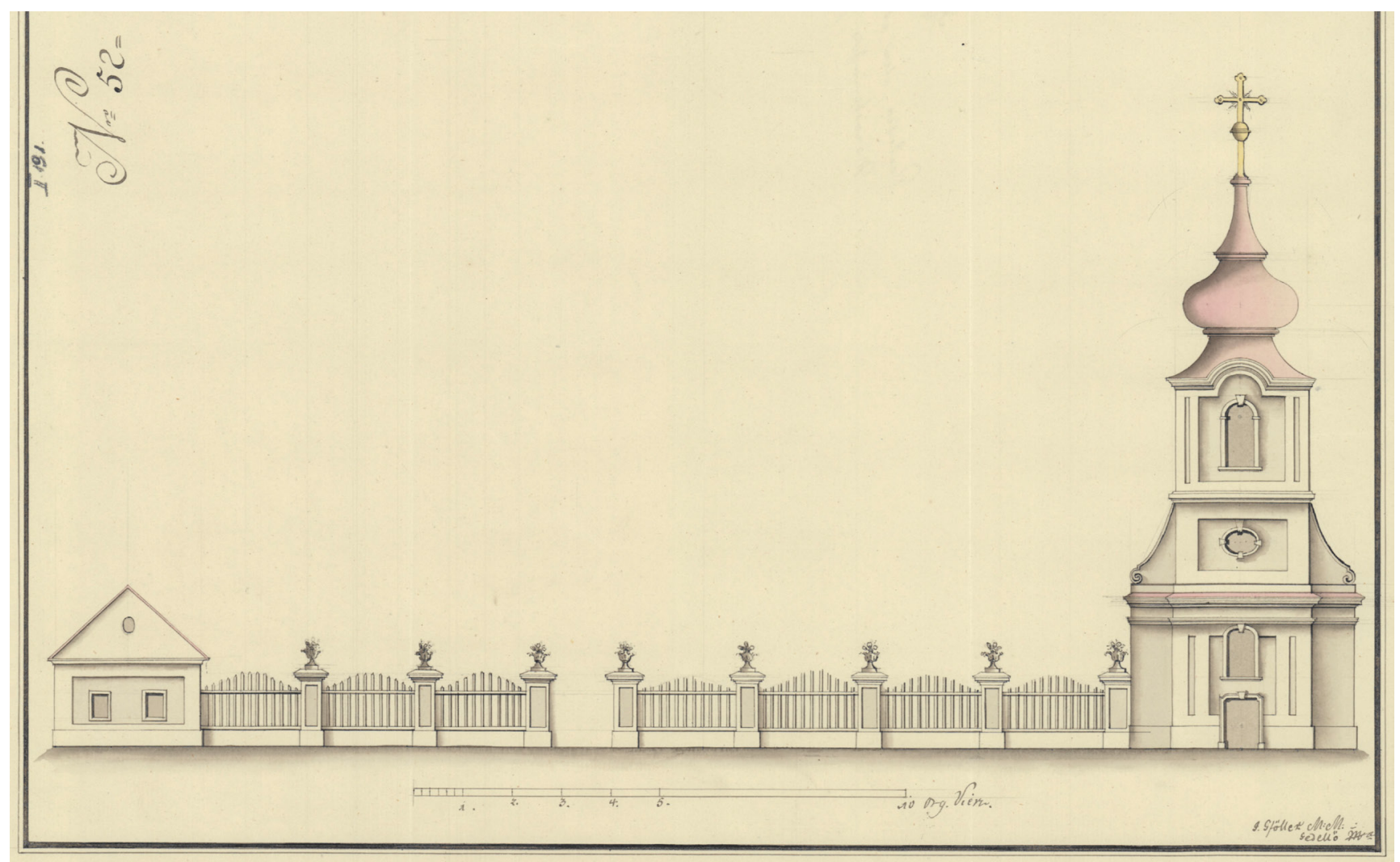

Fig. 9 The facades of the Roman Catholic church and teaching house. Jacob Gföller, 18 $8^{\text {th }}$ century (MNL OL T1 II. 191/2.). Legend (in German): "Faciate der Monostorer Kirchen und Schulmeisters wohnung".

The damage caused by the flood of 1838 was detailed as follows: it damaged the altar, tabernacle and the sculpture (!) of the Holy Trinity, as well as the furnishings, "because they were under water for a couple of days". ${ }^{28}$ The altar, the tabernacle and the sculpture of the Holy Trinity was renovated around 1840 but the stairs towards the choir were still in bad condition, and the inside of the church was in need of a whitewash. After the flood of 1838, it happened only in 1845 , when the inside of the church became renovated, replacing the damaged one, a new altarpiece was painted, which was restored in 1903 (Dercsényi, 1958:II..p.140).

The parish priest appealed to the Ministry of Finance, as patron, in 1874 requesting "the repairment of the numerous considerable imperfections found in the church and the priest house". ${ }^{29}$ The huge flood of 1876 caused a damage of another 1200 forints, the inside of the church was then painted in 1877.

A detailed inventory was made yet again in 1883 including the equipment of the church. It includes the "big lantern in front of the altar", the "small lantern in front of Holy Virgin Mary", 6 pieces of big and 2 pieces of small gilded candle

28 SZPL 4542. Can. Vis. 1868. (Collection of I. Kuthy) holders on the main altar. ${ }^{30} \mathrm{By}$ this time, four candle holders were there in front of the picture of Holy Virgin Mary. The inventory also records the baptistery, the cupboard of uniforms made of softwood, table and chair, 5 pieces of twoheaded and 4 one-headed gilded candle holders on the wall. It lists the two angels on the altar, one Lord's Lamb, one footstool, one "kneeling chair for the parish clerk", the baptistery made of marble, 10 pieces of bigger and 23 smaller pictures, the coffin of Christ, and three bells: one measuring three, one weighing two and one with one quintals. As recorded, the building of the church "was painted on the $1^{\text {st }}$ of July 1883 , found in good condition".

The patron demolished the old fence of the church in 1891, its building materials were put on auction and a new one was made. ${ }^{31}$

Another paint was in need in 1898. The dean curate of Pilisszántó reported in June that the top of the church of Szigetmonostor is being renovated in the same year by the

30 SZPL 4542. 842/1883. Inventory. Inventories made in 1889 and 1890 were not different from this previous one. SZPL 4542. Sz.n./1889; 855/1890.

31 SZPL 4542. Sz.n./1938. 


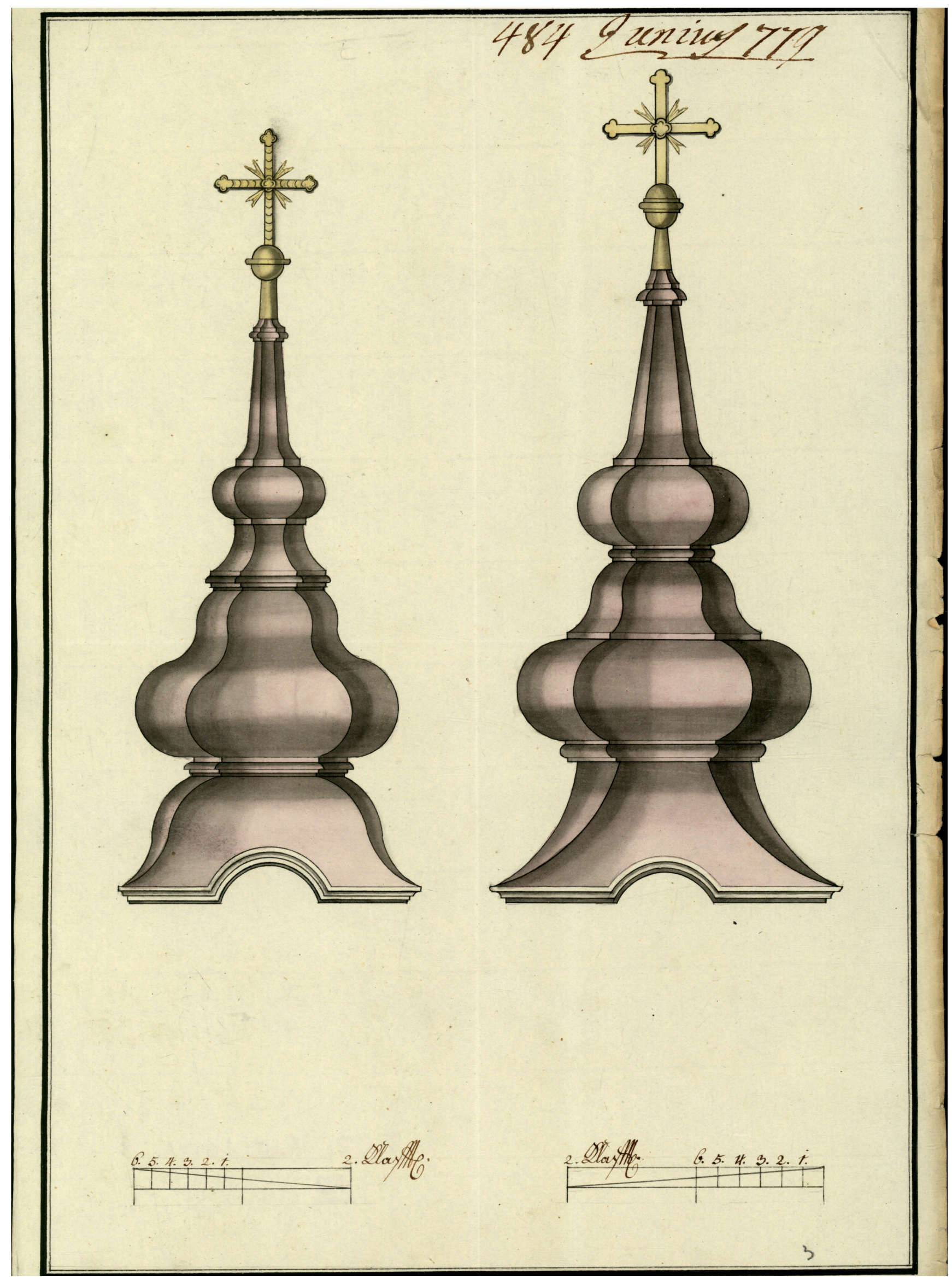

Fig. 10 Steeple to be built on the tower of the Catholic church in Monostor, two versions. Caspar Reischl, 1779. (MNL OL T62. No. 179.) 


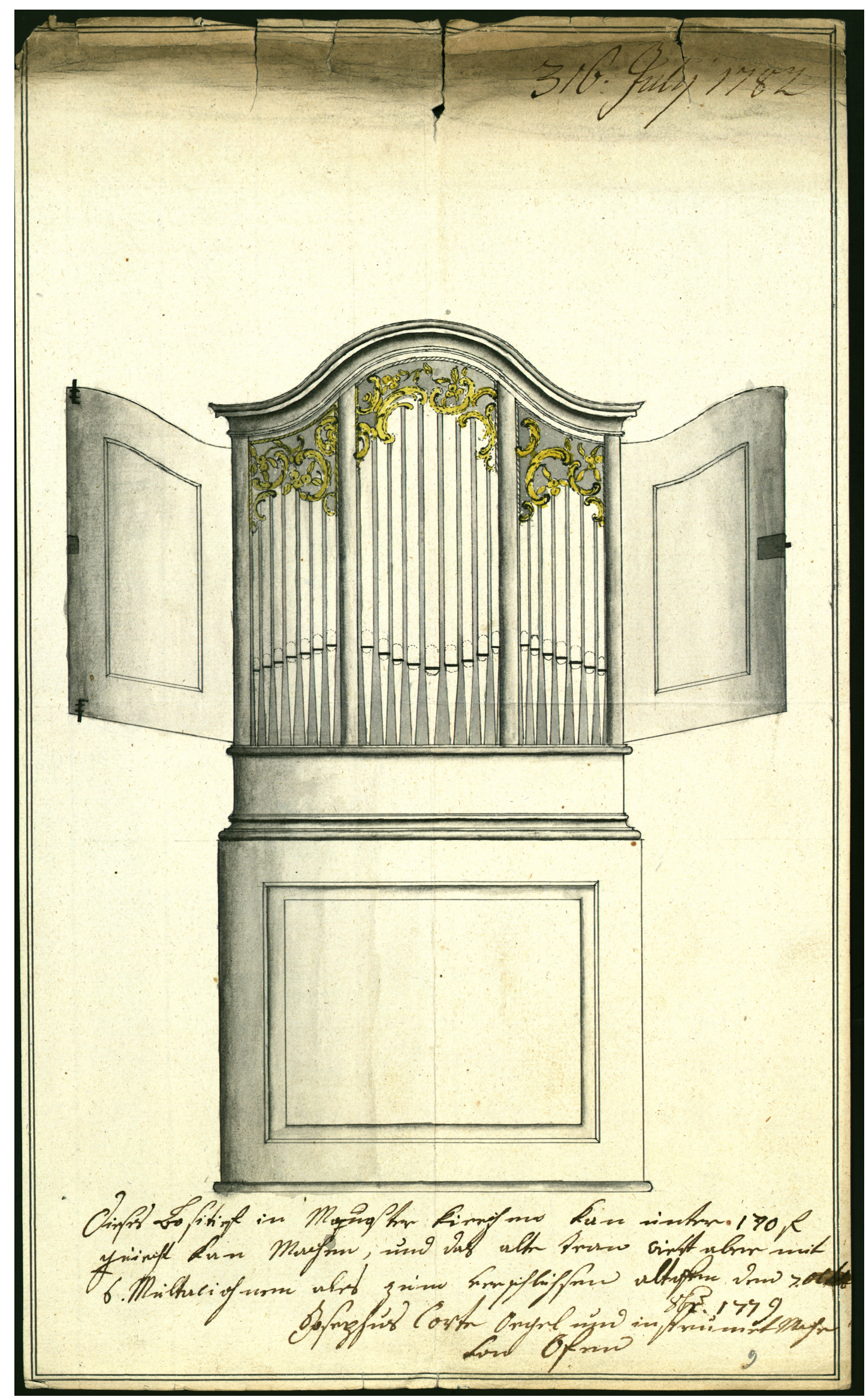

Fig. 11 Plan of the positive organ of the church in Monostor Josephus Corte, organ and musician master of Buda. Óbuda, October 1779 (MNL OL T62. No. 216/8.). 
Chamber. ${ }^{32}$ Presumably, the roof repairment did happen accordingly, this is signed by an inscription of 1898 cut into the $2^{\text {nd }}$ main truss of the roof counted from the tower. The parish reports recorded smaller expenses too: in 1883 they covered the costs of "providing with new glass panes the windows, glass doors and lanterns" and also that of "making windows" in $1896 .{ }^{33}$

\subsection{Renovations of the $\mathbf{2 0}^{\text {th }}$ century}

The Holy Virgin Mary sculpture of Lourdes was acquired with the help of the worshippers and the Altar of Lourdes was raised in 1900 by building the rock cave upon the late Holy Sepulchre. ${ }^{34}$ It was also in 1900 when the benches being used today were made, the year was recorded on the front board of the first bench.

The Chamber as patron made renovation works on the church at the beginning of the 1900s. It was in 1902, when the Minister of Agriculture approved both the internal and the external renovation, which was carried out accordingly. ${ }^{35}$ In the same time, the parish priest requested price offers from some painters for the restoration of the altarpiece, the work was finished by $1903 .{ }^{36}$ The worshippers painted the church in 1907, the expenses were covered with the help of the Chamber and the church fund. ${ }^{37}$

The interior design of the church was depicted by a postcard $^{38}$ and a photograph (Fig. 12): the altar-table and the tabernacle of the original main altar, with a Christ sculpture upon it together with angels by its sides and an altarpiece depicting the Holy Trinity behind it. The picture was framed by a pseudo perspective, Baroque altar architecture painted on the back wall of the sanctuary, with two

32 SZPL 4542. No. 479/1867. Draft 31 December 1866

33 TP Protocollum Parochiae Monostor from 1856.

34 SZPL Collection of I. Kuthy; 4542. 1663/1898; 472/1900; Sz.n./1938; TP Protocollum Parochiae Monostor from 1856.

35 SZPL 4542. From the documents attached to the Can. Visitatios According to other sources: The Ministry of Agriculture renovated the church in 1902 and 1921. (Dercsényi 1958:II.:p.140) And "the roof of the church was repaired in 1902" according to "Szigetmonostori Szentháromság plébánia" (See the website of the Esztergom-Budapest Főegyházmegye: https://www.esztergomi-ersekseg.hu/plebaniak/ szentharomsag-plebania-szigetmonostor).

36 SZPL 4542. From the documents attached to the Can. Visitatios (Collection of I. Kuthy).

37 SZPL Collection of I. Kuthy; 4542. Sz.n./1938.

38 TP; Herrer collection; Museum of Zemplén, Szerencs 0189847; 92093; Published by: Herrer, 2007:p.13. painted apostles on both sides. The baptistery was standing close to the pulpit. The altar of Holy Virgin Mary of Lourdes is on the southern side together with another Holy Virgin Mary sculpture next to it, with a wooden carved gothic architecture above both of them. Apart from the benches carved in 1900, a smaller bench can be seen on the evangelic side perpendicular to the bench lines that might have remained from the late benches. (According to a photograph it was still there yet in the 1960s.)

Prebend, archivist of the bishopry, István Kuthy later described and evaluated the internal paintings of the time in detail: "The last time when the church had been painted was in 1903. The painting is pretty much simple, with scarce artistic taste. The frescos are: The Holy Trinity, God's Eye and the picture of the Immaculate. The pictures on the wall are those of Saint Peter and Paul. The picture of the main altar is a simple oil print; lacking artistic value. The Holy Trinity."39

The choir was enlarged by a Prussian cap vault slab towards the church space in 1913 in order to make it possible to place the new organ. New stairs were made too, that might be the present day spiral staircase made of cast iron. The seven solo organ with one keyboard manual was made in the factory of Ottó Rieger in 1914. ${ }^{40}$

The patron informed the parish priest in 1921 that the new cross, the shingle repairments, the plastering and whitewashing of the church will be made ${ }^{41}$ but this had not happened up until the February of 1923. The meeting of the school board described the condition of the church as: "its cross is broken, the roof of the tower is as bad as the rain is already soaking the internal rafters, its walls without plaster look outrageous." ${ }^{142}$

The shingle cover of the roof was replaced by red slate in 1923, but the tower remained the same as before, still covered by wood shingle. ${ }^{43} \mathrm{~A}$ new cross was made and an outside plastering was carried out, too. Following the tile cover in the eighteenth century (see the Hamon survey), the tower had been covered by shingle throughout the nineteenth century and up until 1923 (see Canonica Visitatios),

39 SZPL Collection of I. Kuthy:p.1.

40 SZPL Collection of I. Kuthy; SZPL 4542. Sz.n./1938. Inventory was made in 1918, 1930 and in 1933 too. SZPL 4542. 36/1918; 3368/1930; 2206/1933.

41 SZPL 4542. From the documents attached to the Can. Visitatios (Collection of I. Kuthy).

42 TP Reports taken at the meetings of the school board 1921-1933. Meeting of 22 February 1923.

43 SZPL 4542. Sz.n./1938. 
which was recorded by several postcards (Fig. 13). The condition represented by the slate covered nave and the shingled steeple after 1923 can also be seen on several photographs. This type of roof cover had still existed yet in 1958 (Dercsényi, 1958:II.:p.140).

Regarding the bells, two were taken during World War I. One was acquired by the worshippers, weighing $229 \mathrm{~kg}$ next to the remaining two; it was benedicted by county bishop Ottokár Prohászka in 1923. ${ }^{44}$

During the spring of 1935 the ceiling of the southern sacristy fell down and broke the confessional. Székesföváros, as new patron renovated the church: it was replastered on the outside, whitewashed, the roof was repaired, the two sacristies (probably those of the slab and the roof structure) were lifted by $20 \mathrm{~cm}$, the slumped roof was rebuilt. (The roof structures of the sacristies have probably been covering the sanctuary's windows since this time). The slab above the gallery in the tower was boarded up from below. By breaking through the vault the stairs to the choir were moved to the porch "fitting exactly in the southern recess made up of the three walls in direction of the choir through the slotted vault". ${ }^{45}$ (There is no data found on the previous approach of the choir, it might be situated in the church space, slotting the vault in front of the present day confessional, because it is there, where supplementation within the strip floor can be seen.)

The internal gate - that was built as the main gate of the church without tower with identical carving as the external has - was moved to the plane of the internal wall. The beautifully carved face was walled up. As a result of this, the holding capacity of the church has become extended by the space under the tower. The floor level was raised to the level of the church floor. Still, the original Kehlheim flooring of the church can only be found here, in the northern niche of the space under the tower. They did not care about internal renovation: the interior is described as "worn-out" in 1937. It was still "worn-out" in 1940 and the windows were in bad condition too. The confessional had been "broken into pieces" since $1935 .{ }^{46}$

The church did not suffer any war-related damage in World War II, smaller expenses were to be made only for glazing the windows. Taking photos of the main altar in

44 SZPL Collection of I. Kuthy.

45 SZPL Collection of I. Kuthy. p. 5.

46 SZPL 4542. 2476/1937; Sz.n./1938; 2737/1940.
1950 is also listed among the expenses ${ }^{47}$, according to the photo, the internal space had not changed compared to the previous condition.

Expenses were made for the organ in 1950, for the windows and the door in 1955, and for the repairs of the slated roof in 1958. Window repairs and glazing happened in 1961, 400 forints for the acquisition of materials for the roof is among the list of expenses in $1967 .^{48}$

The internal space of the church changed significantly in 1952. In place of the former painted architecture, Ernő Jeges $^{49}$ painted a main altarpiece fresco, depicting the Holy Trinity together with four archangels (Michael, Gabriel, Raphael and Uriel), with Hungarian saints (St. Stephen, St. Emery, St. Margaret, St. Eizabeth, and St. Ladislas), as well as the village represented in the middle of the picture. The other pictures on the vaults and the two sidewalls of the sanctuary are his works, too. Probably the previous painting remained under the new frescos, as analysing the lower damaged section of the painting in the sanctuary, traces of previous layers were found in $1997 .{ }^{50}$ The further fate of the late altarpiece is unknown.

Two photographs were taken of placing a sacrificial grid in front of the sanctuary probably in the 1950s. The caption of the triumphal arch at that time was: "Queen took into heaven, please, pray for us" with smaller letters than those of today, within a simple string frame. The pulpit in the inner space was still painted brown (Dercsényi, 1958:II.:p.140), an iron stove close to it was operating for a long time that's chimney hole can still be noticed in the loft.

The steeple was repainted in $1963 .{ }^{51}$ The replacement of the steeple cladding happened in the 1960s, too, the exact date is not known. Metal slab cover was built instead of shingle. This repainting in 1963 might already have affected the

47 SZPL 4542. 553/1945; TP Church statements 1938-1967; Photocopy of the photograph.

48 TP Church statements 1938-1967.

49 Ernő Jeges (1898-1956) painter, graphic, the distinctive representative of the so-called Roman school style. (Zádor and Genthon, 1966:II.:pp.514-515; Kenyeres, 1967:I).

50 Traces of red-brownish base paint with horizontal trims could be found under the abolished panelling, at the back part of the sanctuary, under the trim of the Jeges fresco. The placement draft of the altar sketched on the wall could be recognized as well as the plinth of the painted columns. (According to the document a photograph was also taken of the artefact.) The researcher advised to maintain the plaster in this sector. TP Report of Pál Lővei about the going-over, 1997.

51 SZPL 4542; TP 1587/1963. 


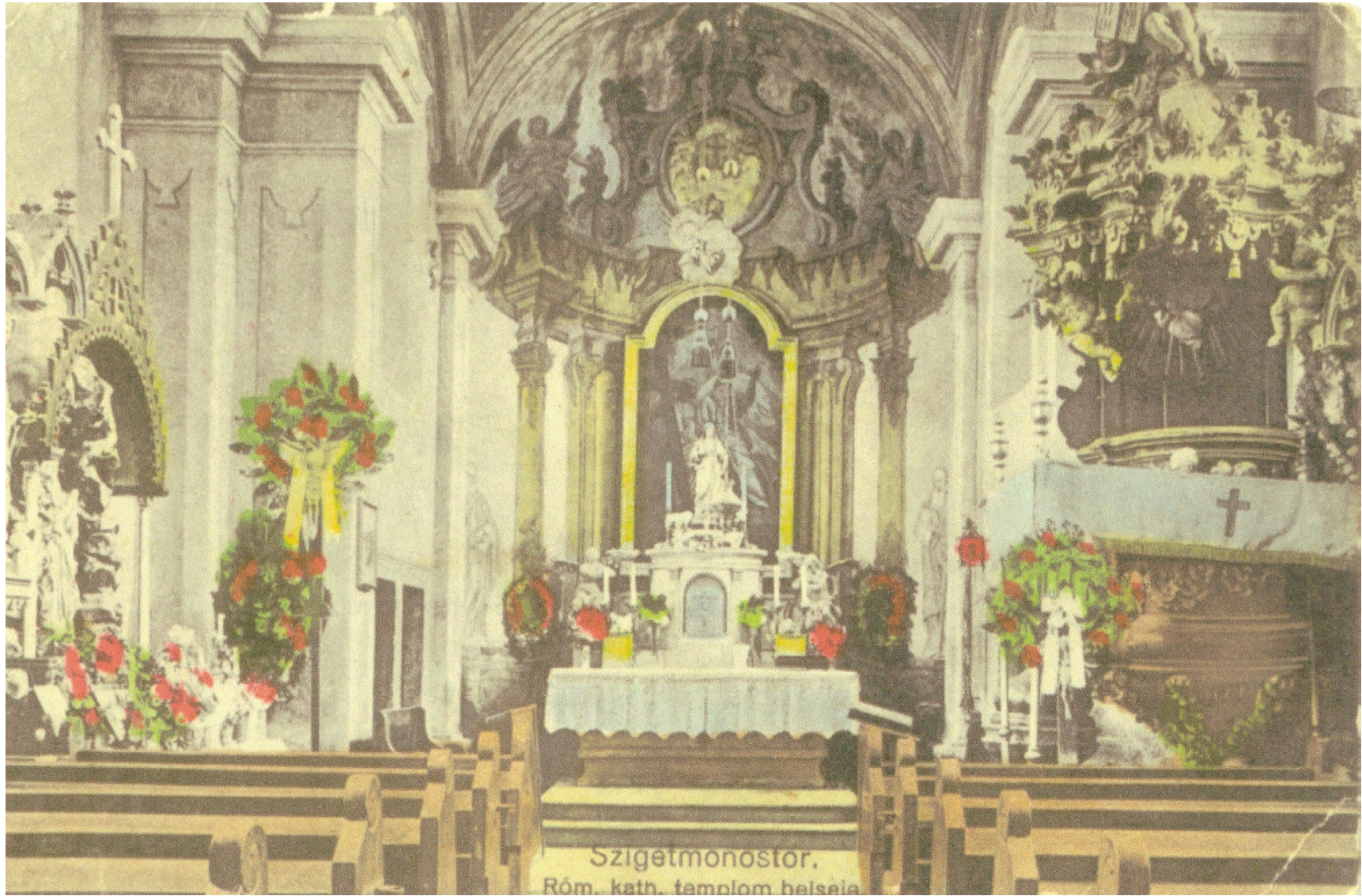

Fig. 12 Szigetmonostor, internal space of the Roman Catholic church. Postcard, before 1933, published by György Monostory, Budapest (TP; Herrer collection; published by Herrer, 2007:p.13).

tin roof. Several photographs survived depicting the condition of the church with its slate covered roof and tin steeple, yellow walls in which the stone frames are painted white, the blind holes are walled up until the plane of the wall.

A budget was submitted to the Diocesan Authority of Székesfehérvár about the renovation of the church in 1964, asking for permission from the State Church Office. The budget was not accepted immediately, but finally the work was carried out, because mason settlings survived. ${ }^{52}$

The new liturgic space was created in 1969 , the late altar was taken out from the chancel into the place of the Holy Virgin Mary of Lourdes. The former tabernacle still stands on the Holy Sepulchre altar. The present day main altar and the ambo were moved to the sanctuary, as part of the liturgical space formed according to the decision of the Second Vatican Council. Until the creation of the above mentioned, a wooden reading desk painted white had also been the part of the furnishings. ${ }^{53}$

52 TP Registration book 1963-1969; SZPL 4542. 1433/1964.

53 SZPL 4542. 1137/1969.
The walls highly exposed to wetting were covered by panelling, the stone surfaces were painted by artificial marble in the 1970s. The photographs of the period showed that the wet stains appeared above the panelling too, as well as the confessional built into the southern niche under the gallery.

An inventory was made in 1984 noting, that the internal plinth is covered by panelling. ${ }^{54}$ The wood fence with stone plinth was built in the 1980 's..$^{55}$

Greater renovation works were taking place between 1986-1987. The tower got a lightning rod, the steeple was repaired and repainted. The full renovation of the roof, the substitution of the late slated roof also happened this time. An electric heat storing stove provided heating, bells had become electrified by the time. ${ }^{56}$ "The plaster was brought down at full height, replastered" (probably on the external surfaces). The cleaning and repairment of the stone frames were also done, and the small Ancient Roman stone

54 TP Inventory 1984

55 According to the communication of Elemérné Hanó, ex-sacristan.

56 TP 34/1986. Can. Vis. Before confirmation; SZPL 496/1986; 631/1986; 1282/1986; 819/1987. 


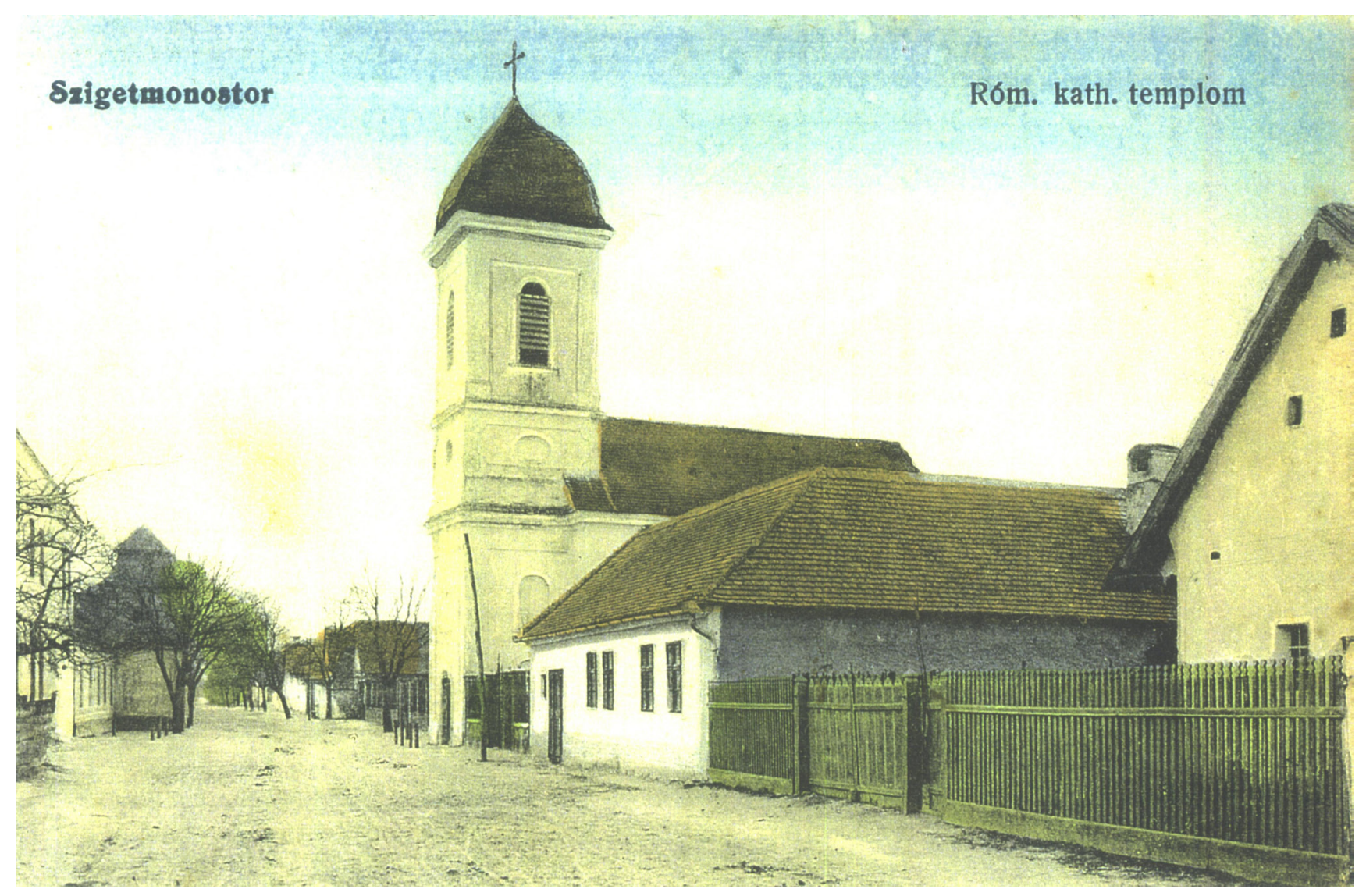

Fig. 13 Szigetmonostor. Rom. Cath. Church. Postcard, published by Mórné Goldstein, 1918 (Herrer collection, Szigetmonostor, published by Herrer, 2007:p.13).

sculpture (Mráv, 2021) was conserved on the main façade. On the two lower levels of the tower the stone frames of the blind holes were extricated. ${ }^{57}$

In November, 1987 the Országos Müemléki Felügyelőség (OMF, National Monument Inspectorate) acknowledged the finished renovation. It proposed the renovation of the external windows, as the next step. "The church still has its original wooden windows, and the very good quality - although single-layered - structures are covered by lowgrade steel windows placed in different planes and heights." ${ }^{58}$

The plans of the church were assessed in $1993 .{ }^{59}$

57 TP 46/1987. Letter of Pál Bednár parish priest, budgets, letters 619/1987; 212/1987; report 19/1987. The OMF authorization: OMF.11024/1986. Péter Klaniczay. (Plan and photodocumentation are at unknown place).

58 TP 12524/1987. Letter of András Román 24 of November, 1987. "It needs to be investigated, whether thermo-insulating glass could be put into the original windows, because by removing the steel windows, the facade of the church, that can be seen from far away, would be enriched reasonably, and which is already decorated by the renovated stone frames, but the steel windows spoil the combined sight."

59 TP Surveys and plans. M 1:100. Imre Mócsai, 1993.
The OMF approved the survey authorization documentation in $1997 .{ }^{60}$ It was the time when panelling was removed and the lower part of the wall was plastered by drying plaster. Instead of the previous green color the internal walls were painted white. The stone plinths and frames were also restored. ${ }^{61}$ The wooden structures of the doors and windows were painted to dark green, the grids and bars received matte black paint. Electric heating was installed into the benches in 1998, the tower was repainted in 1999 and the old wooden bellfries were replaced by iron scaffolding.

The frescos of Ernő Jeges were restored between $2000-2002,{ }^{62}$ then the cupboard of the organ in $2002 .{ }^{63}$ The tabernacles together with the Baroque angels were

60 TP The survey authorization documentation of the renovation. A. Jámbor 1997. (Plans M 1:100, archive photos and also taken that time).

61 TP Renovation proposition regarding the restorational works of the internal plinth and the stone surfaces of the windows and doors. F. Gergely Kriszt, 1997.

62 TP Artistic description and renovation proposition to the fresco cycle painted by Ernő Jeges. Gy. Tarr, 2000. Restorational photo documentation. Gy. Tarr, 2002.

63 TP The restoration plan of the organ cupboards. R. Schwartz 2001. 
renovated in $2002,{ }^{64}$ then the restoration of the pulpit with high standards came between 2004-2007. Following a deep research it was renovated in its original colors (blue-brown) and form instead of the white-gold toning. ${ }^{65}$ In 2017-2018, the steeple was renovated when a new copper plate cover was made. Contrary to the timber protection expert opinion and the restoration plan, the contractor replaced the entire roof structure of the tower. ${ }^{66}$

\section{Conclusion}

The church of Szigetmonostor, together with the parish building in front, and the late chanter house next to it, is the characteristic complex of its environment determining the village picture. Although, it is not part of the frontrank, monumental relics of the era, it has a worthy place within provincial Baroque architecture.

When this church was built in the middle of the eighteenth century, by taking back its position, repelling protestant denominations as possible, on the peak of its authority the Catholic Church was characterized by rich building activity and vivid artistic style. The distinctive architectural style of the period, Baroque architecture, was marked by striving for fancy magnificence, scenic effect and the application of the new possibilities of light and shadow effects. In rural architecture, in line with the size and peculiarities of the task, this occurred in a more modest, less powerful plastic language, but in the same time not lacking the eminent elegancy.

The church of Szigetmonostor, together with its plan arrangement, its vault design is part of the one naved churches extended by niches that became characteristic of the middle of the eighteenth century. Compared to the former side chapel type, the church space has become organic with this simplification. From 1730 until the end of the century, the internal space of the churches were covered by a row of Bohemian (spherical) vaults that were separated by arching. The arches were leaning to lesenes jutting out from the side wall plane of the nave, hereby, in contrast to

64 TP The restoration plan of the altar and the pulpit. The restoration documentation of the altar and the pulpit, R. Schwartz (2002) The altar was renovated by Rezső Schwartz wood sculptor (Dunabogdány) in 2002, but the pulpit was restored finally by Zsuzsanna Szőnyi wood sculptor restorer (Tahitótfalu).

65 TP The $18^{\text {th }}$ century pulpit. Research preparation. Zs. Szönyi, 2004; Result of the research. Zs. Szőnyi, 2004.

66 TP Timber protection expert opinion. E. Molnár 2016.; Preliminary structural expert opinion. T. Méri, 2016.; Authorization plan, G. Gyetvai, 2016. the previous solid wall frame network the structure became pillar based (Andorné Tóbiás, 1974:pp.349-350). From the three vault sections of the church of Szigetmonostor, the middle one is longer and wider then the rest, which is not a frequent solution of the era. This vault section appears on the external mass, too, supported by a bigger wall thickness. As a result, the side façade became more plastic, too.

The middle tower façade solution became widely used in the middle of the eighteenth century in Hungary. By leaving the side chapels behind the main façade became reasonably narrower, thus, this solution fit its proportions in a better way. The nave of the church of Szigetmonostor is not much wider than its tower, which did not favour its proportions. The tower being built later to the nave $-\mathrm{a}$ recurring building method of the churches of the time was identified here, too, during the inspection of the wall texture within the tower. With its simple façades, unified but still well-proportioned mass, this church is a beautiful example of Baroque village churches.

The internal space formation of the one naved church is especially good proportioned, ceremonial. The good lighting provided by the big arched windows is expanding the spaciousness of the visually organic space. The wall pillars and the strongly jutting out entablatures strengthen the movement of the space, amplify the play of light and shadow. One can also meet this uncommon phenomenon of the patron oratorio formed on the ground floor next to the sanctuary (present day southern sacristy).

The most valuable part of the building in terms of art is the pulpit that is a very high quality late Baroque piece renovated while keeping its original appearance. The frescos painted by Ernő Jeges are high quality works of the parochial paintings of the twentieth century.

The original designer of the church is unknown that is also true for the most part of the building stock of the eighteenth century. It was also frequent in the period, that the plan was purchased from somewhere and the execution was given to a local craftsman, but there were several times when chamber type plans were used too. This is improbable here, because the wider vault section was not a typical solution. Maybe, one could find the designer/ implementer among the master masons of Buda or Pest, because, by this time, the national master mason, building master layer already got a significant role besides foreign artists arriving to Hungary. The masters of the period were characterized by reliable technical knowledge, good professional efficiency, proven by the organic formation of the vaults of the church of Szigetmonostor. 


\section{References}

Andorné Tobiás, J. (1974) "A XVII-XVIII. századi Magyarország barokk templomépítészetének szerkezeti kialakulása és fejlődése" (The structural formation and development of the Hungarian Baroque church architecture), Építés- Építészettudomány 6(3-4), pp. 341-386.

Bakács, I. (1963) "A Zichy család levéltára. Repertórium" (Archives of the Zichy family. Repertory), Müvelődésügyi Minisztérium Levéltári Osztálya, Levéltárak Országos Központja, Budapest, Hungary. (in Hungarian)

Borovszky, S. (ed.) (1910) "Magyarország vármegyéi és városai. PestPilis-Solt-Kiskun Vármegye I." (Counties and cities of Hungary. Pest-Pilis-Solt-Kiskun County I. ), Országos Magyar Monográfiai Társaság, Budapest, Hungary. (in Hungarian)

Bottlikné Grósz, Á. (2007) "Szigetmonostor története" (History of Szigetmonostor), Herrer, Budapest, Hungary, 2007, pp. 8-20. (in Hungarian)

Dercsényi, D. (ed.) (1958) "Pest megye müemlékei" (Monuments of Pest county), Akadémiai Kiadó, Budapest, Hungary. (in Hungarian)

Esztergom-Budapest Főegyházmegye "Szigetmonostori Szentháromság plébánia" [online] Available at: https://www.esztergomi-ersekseg. hu/plebaniak/szentharomsag-plebania-szigetmonostor [Accessed: 18 July 2020]

Genthon, I. (1951) "Magyarország müemlékei" (Monuments of Hungary), Akadémiai Kiadó, Budapest, Hungary. (in Hungarian)

Gerevich, L. (ed.) (1986) "Pest megye régészeti topográfiája. A Budai és a Szentendrei járás" (Archeological topography of Pest county. The territories of Buda and Szentendre), Akadémiai Kiadó, Budapest, Hungary. (in Hungarian)

Gólya, J. (ed.) (1960) "Mủemlékjegyzék" (Monument catalogue), Müszaki Kiadó, Budapest, Hungary. (in Hungarian)

Gy. Balogh, Á. (1998) "Buda Főváros kőműves és kőfaragó céhe mesterei" (The masters of the Mason and Stone-cutter Guild of the Capital Buda), Építés- Építészettudomány, 27(3-4), pp. 269-333. (in Hungarian)

Gy. Balogh, Á. (2000) "A szigetmonostori r. k. plébániaépület helyreállítása" (The renovation of the Roman Catholic parish building in Szigetmonostor), [manuscript] Műemlékvédelmi tudományos dokumentáció (Scientific documentation of monument protection). (in Hungarian)

Gyetvainé Balogh, Á. (2008) "Adalékok Szigetmonostor XVIII. századi történetéhez" (Data to the history of Szigetmonostor in the XVIII. century) Építés - Építészettudomány, 36(3-4), pp. 189-221. (in Hungarian)

https://doi.org/10.1556/eptud.36.2008.3-4.4

\section{Archival sources and documentations}

MÉM Fotótár - Magyar Építészeti Múzeum és Dokumentációs Központ, earlier Forster Gyula Nemzeti Örökségvédelmi és Vagyongazdálkodási Központ - Fotótár (Hungarian Museum of Architecture and Monument Protection Documentation Centre, earlier Gyula Forster National Heritage Protectional and Wealth Management Centre - Photo gallery)

- Pictures of 43508; 43509; 74098.
Gyetvainé Balogh, Á. (2016) "Szigetmonostor Szentháromság plébániatemplom" (The Holy Trinity parish church in Szigetmonostor), [manuscript] Építéstörténeti tudományos dokumentáció (Construction historical scientific documentation). (in Hungarian)

Gyetvainé Balogh, Á. (2020) "A szigetmonostori Szentháromság plébániatemplom építéstörténete és müemléki kutatása" (History of the construction and monumental survey of the Holy Trinity parish church in Szigetmonostor), Műemlékvédelem, 64(1-2), pp. 30-54. (in Hungarian)

Györffy, Gy. (1998) "Az Árpád-kori Magyarország történeti földrajza" (Historical geography of Hungary during the Árpád era), Akadémiai Kiadó, Budapest, Hungary. (in Hungarian)

Herrer, M., C. (ed.) (2007) "Szigetmonostor Anno. A település története. Szigetmonostori családok fotóalbuma" (The history of the municipality. Photo albums of the families of Szigetmonostor), Szigetmonostori Faluszépészeti Egylet, Szigetmonostor, Hungary. (in Hungarian)

Horler, M. (1962) "Budapest műemlékei" (Monuments of Budapest), Akadémiai Kiadó, Budapest, Hungary. (in Hungarian)

Ikafalvi Diénes, V. (ed.) (1990) "Magyarország műemlékjegyzéke" (Monument catalogue of Hungary), Országos Müemléki Felügyelőség, Budapest, Hungary. (in Hungarian)

Kenyeres, Á. (ed.) (1967) "Magyar életrajzi lexikon 1000-1990" (Hungarian Biographical Cyclopedia 1000-1990), Akadémiai Kiadó, Budapest, Hungary. (in Hungarian)

Kiss Tamásné Mikolai, Á. (ed.) (1996) "Emlékezet könyve. A szigetmonostori Református Egyház története" (Book of Memory. The history of the Calvinistic church in Szigetmonostor), Ráday Nyomda, Szigetmonostor, Hungary. (in Hungarian)

L. Gál, É. (1988) "Az óbudai uradalom a Zichyek földesurasága alatt 16591766" (The manor of Óbuda under the reign of the Zichys between 1659-1766), Akadémiai Kiadó, Budapest, Hungary. (in Hungarian)

L. Gál, É (2004) "Tahitótfalu múltjából (XVI-XVIII. század)" (From the past of Tahitótfalu (XVI-XVIII. centuries)), Tahitótfalu Község Önkormányzata, Tahitótfalu, Hungary. (in Hungarian)

Mráv, Z. (in press) "Két közöletlen feliratos római oltárkő Szigetmonostorról (Pest megye)" (Two unpublished Roman inscribed votive altars from Szigetmonostor (Pest County, Hungary)), Studia Epigraphica Pannonica 12.

Pehm (Mindszenty), J. (1934) "Padányi Biró Márton veszprémi püspök élete és kora" (The life and time of Márton Padányi Biró, bishop of Veszprém), Zalaegerszeg, Hungary. (in Hungarian)

Zádor, A., Genthon, I. (eds.) (1966) "Müvészeti Lexikon" (Art cyclopedia), Akadémiai Kiadó, Budapest, Hungary. (in Hungarian)

MÉM Tervtár - Magyar Építészeti Múzeum és Dokumentációs Központ, earlier Forster Gyula Nemzeti Örökségvédelmi és Vagyongazdálkodási Központ, Tudományos és Gyűjteményi Főosztály - Tervtár (Hungarian Museum of Architecture and Monument Protection Documentation Centre, earlier Gyula Forster National Heritage Protectional and Wealth Management Centre, Department of Science and Collection - Plan gallery)

- Report about the renovation of the frescos (1997)

- Restorational documentation of the pulpit (2006) 
MNL OL - Magyar Nemzeti Levéltár Országos Levéltára (National Archives of Hungary)

-E 58. 1779. jún. No 484.; E 58 1782. júl. No 316;

- P 707. Zichy család levéltára, [Archives of the Zichy family] Vol. 601. Ferenc Radnai: Zichy nemesi és grófi család története, életrajza és leszármazása. [Patrician and earl family history, biography and ancestry of the Zichy family] Manuscript, end of the $19^{\text {th }}$ century

- S 11. No. 830:1-97. Kneidinger Atlas; No. 830:68; No. 34; No. 830:70; No. 830:82

- T1 II. 191/1-2;

- T62. No. 179; No 216/8.

SZPL - Székesfehérvári Püspöki és Székeskáptalani Levéltár (Archives of Székesfehérvár Bishopry)

- The documents concerning the parish of Szigetmonostor: 4542. No. 479/1867; No. 1523/1874; No. 25/1878; No. 842/1883; Sz. n./1889; No. 855/1890; Sz. n./1896; No. 1663/1898; No. 1738/1898; No. 1968/1898; No. 472/1900; No. 36/1918; No. 3368/1930; No. 2206/1933; No. 2476/1937; Sz.n./1938; No. 575/1939; No. 2737/1940; No. 553/1945; No. 1587/1963; No. 1433/1964; No. 1137/1969; Sz. n./1981; No. 496/1986; No. 631/1986; No. 1282/1986; No. 819/1987; 1672/70. plan M 1:100, w. d.;

- Collection of István Kuthy prebend, archivist of the bishopry (including Canonica Visitatios)
TP - Tahitótfalui Szent István király plébánia ${ }^{69}$ (Parish of King St. István in Tahitótfalu, managing the church of Szigetmonostor, too) - documents; postcards, old register books from Szigetmonostor (1940-1949; 1963-1969);

- Protocollum Parochiae Monostor from 1856;

- Templomi számadások könyve 1938-tól [Book of church statements from 1938];

- Reports recorded on the Roman Catholic school board seats of Szigetmonostor between 1921-1933;

- The plan of the Roman Catholic church in Szigetmonostor. Base. Choir. Survey plan. M 1:100, n. n., (before 1935);

- Documentations concerning the church of Szigetmonostor and parish building:

- Roman Catholic parish church of Szigetmonostor, survey plan, ground-plans M 1:100. Imre Mócsai, 1993.

- Renovation proposition regarding the restorational works of the internal plinth and the stone surfaces of the windows and doors, F. Gergely Kriszt, 1997;

- Authorization plan documentation of the restoration of the R. C. Church of Szigetmonostor, Andrea Jámbor, 1997;

- Artistic description and renovation proposition to the fresco cycle painted by Ernő Jeges, György Tarr, 2000; Restorational photo documentation, Gy.Tarr, 2002;

- The restoration plan of the altar and the pulpit, Rezsö Schwartz (2001);

- The restoration documentation of the altar and the pulpit, R. Schwartz, (2001);

- Restoration documentation, R. Schwartz (2002);

- The 18th century pulpit. Research preparation, Zsuzsanna Szőnyi, 2004, Result of research, Zs. Szőnyi, 2004;

- Timber protection expert opinion. Eszter Molnár 2016;

- Preliminary structural expert opinion. Tamás Méri 2016;

- Survey plan, Géza Gyetvai, Péter Gyetvai, Vince Nemes 2016.

- Authorization plan, Géza Gyetvai 2016.

69 The old books preserved by the parish church of Szigetmonostor were moved to the parish of Tahitótfalu at the end of 1990's "for the sake of preservation and salvation". Pál Bednár parish priest complained in one of his letters, that he did not find the records of neither Historia Domus, nor Canonica Visitatio, therefore, he is not able to help the research of the history of the parish. He moved the parish registers to Tahitótfalu in the 1980 s. 